University of Louisville

ThinkIR: The University of Louisville's Institutional Repository

Electronic Theses and Dissertations

$5-2013$

\title{
The effect of cervical cancer on survivor's sexual dysfunction and quality of life.
}

Katie F. Myatt 1986-

University of Louisville

Follow this and additional works at: https://ir.library.louisville.edu/etd

\section{Recommended Citation}

Myatt, Katie F. 1986-, "The effect of cervical cancer on survivor's sexual dysfunction and quality of life." (2013). Electronic Theses and Dissertations. Paper 1033.

https://doi.org/10.18297/etd/1033

This Master's Thesis is brought to you for free and open access by ThinkIR: The University of Louisville's Institutional Repository. It has been accepted for inclusion in Electronic Theses and Dissertations by an authorized administrator of ThinkIR: The University of Louisville's Institutional Repository. This title appears here courtesy of the author, who has retained all other copyrights. For more information, please contact thinkir@louisville.edu. 


\section{THE EFFECT OF CERVICAL CANCER ON SURVIVOR'S SEXUAL DYSFUNCTION AND QUALITY OF LIFE}

By

Katie F. Myatt

B.A., University of Louisville, 2008

A Thesis Submitted to the Faculty of the School of Public Health and Information Sciences of the University of Louisville in Partial Fulfillment of the Requirements for the Degree of

Master of Science

Department Of Epidemiology

University of Louisville

Louisville, Kentucky

May 2013 


\section{Copyright 2013 by Katie F. Myatt}

All rights reserved 


\title{
THE EFFECT OF CERVICAL CANCER ON SURVIVOR'S SEXUAL
} DYSFUNCTION AND QUALITY OF LIFE

\author{
By \\ Katie F. Myatt \\ B.A., University of Louisville, 2008 \\ A Thesis Approved on \\ April 18, 2013 \\ By the following Committee \\ Dr. Richard Baumgartner, PhD \\ Thesis Committee Chair \\ Dr. Kathy B. Baumgartner.
}




\section{DEDICATION}

This thesis is dedicated to my husband, parents, and brother who were instrumental in the completion of this project, and to my daughter Avery who was my motivation. 


\section{ABSTRACT \\ THE EFFECT OF CERVICAL CANCER ON SURVIVOR'S SEXUAL DYSFUNCTION AND QUALITY OF LIFE}

Katie F. Myatt

April 18, 2013

Cervical cancer poses a unique opportunity for researchers who are interested in quality of life. It is one of the most common cancers, has a very high survival rate, and very little research has been conducted to determine the effects of cervical cancer on women post-diagnosis. This goal of this thesis was to determine if cervical cancer survivors were at greater risk of sexual dysfunction due to treatment or stage of disease and to determine if poorer quality of life outcomes were associated with sexual dysfunction and depression. The results found that stage and treatment options put survivors at greater risk for sexual dysfunction and that sexual dysfunction and depression were associated with poorer mental and physical quality of life. 


\section{TABLE OF CONTENTS}

DEDICATION

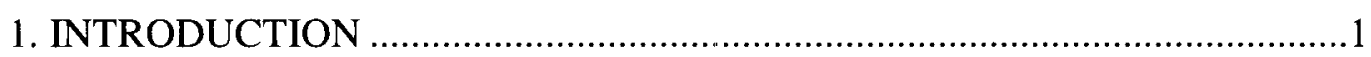

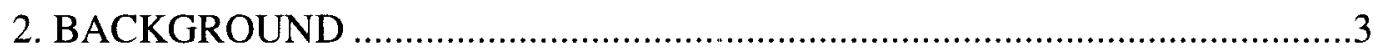

2.1 Epidemiology of Cervical Cancer...........................................................

2.1.1 Risk Factors ...........................................................................

2.1.2 Prevention of Human Papilloma

Virus (HPV) Infection................................................................

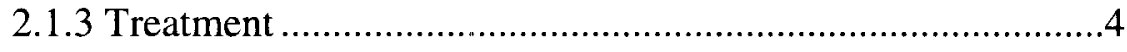

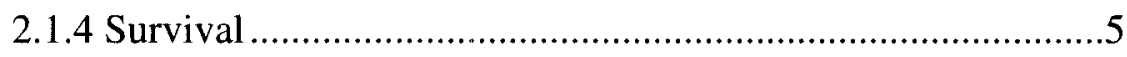

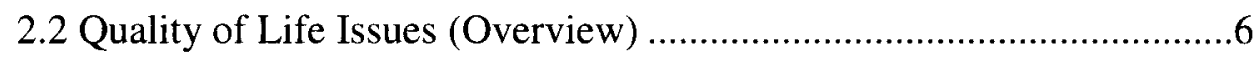

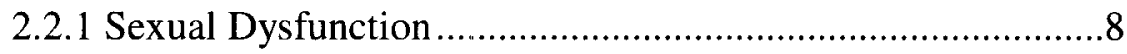

2.2.1.1 Assessing the Impact

of Diagnosis with the

Sexual Adjustment Questionnaire (SAQ) ............................9

2.2.2 Assessing Quality of Life with

the MOS 36-item Short Form Survey (SF-36) ...............................10

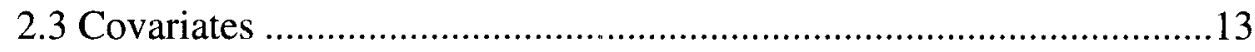

2.3.1 Depression.........................................................................13

2.3.1.1 Impact of Diagnosis with

Relation to the Center for

Epidemiologic Studies-Depression

(CES-D) Scale

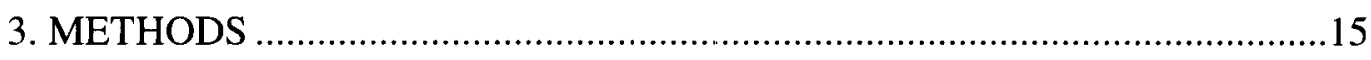

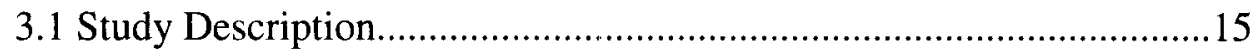


3.2.1 New Mexico

Tumor Registry (NMTR) .....................................................16

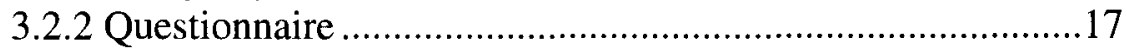

3.2.3 MOS 36-item Short Form

Survey (SF-36), Center for Epidemiologic

Studies-Depression (CES-D) Scale,

and Charlson Comorbidity Index ............................................... 17

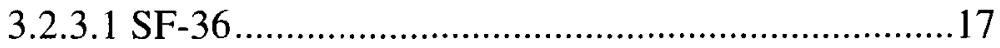

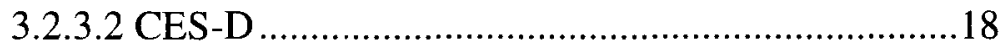

3.2.3.3 Charlson Comorbidity Index................................19

3.2.4 Measures of Sexual Dysfunction ....................................20

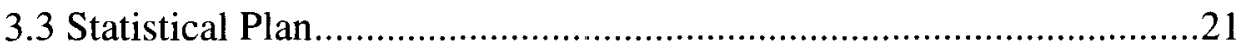

3.3.1 Logistic Regression Models...........................................22

3.3.2 Linear Regression Model ............................................23

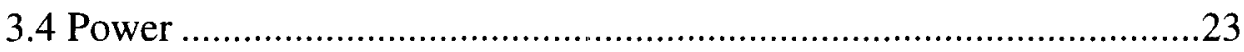

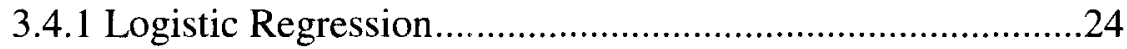

3.4.2 Linear Regression ................................................ 24

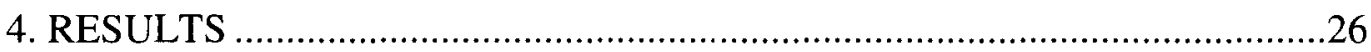

4.1 Descriptive Characteristics of the Sample ....................................26

4.1.1 Demographics ......................................................26

4.1.2 Behavioral and Physical

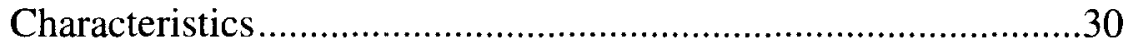

4.1.3 Other Covariates of Interest ............................................33

4.1.4 Outcome Variables.........................................................35

4.1.4.1 Secondary Aim................................................36

4.2 Sexual Dysfunction, Stage of Disease,

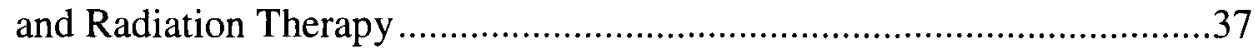

4.3 Depression and Stage of Disease ................................................45

4.4 MOS 36-item Short Form Survey (SF-36)

Physical and Mental Health Summary Scores ....................................50

4.4.1 Physical Health Summary Score, Depression, and Sexual Dysfunction 
4.4.2 Mental Health Summary Score,

Depression, and Sexual Dysfunction

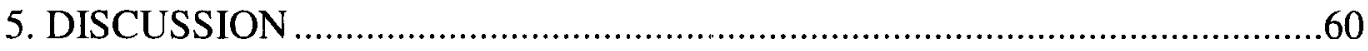

5.1 Associations with Sexual Dysfunction .........................................60

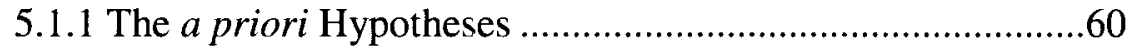

5.1.2 Focusing on the Relationship Between

Sexual Function, Stage of Disease, and Depression ....................61

5.2 Quality of Life and the MOS 36-item

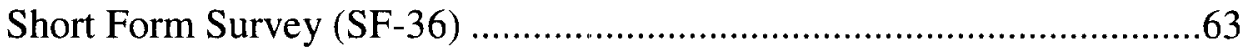

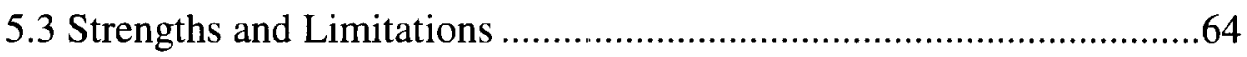

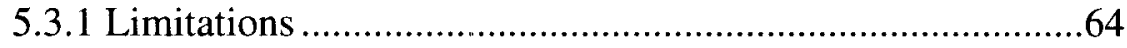

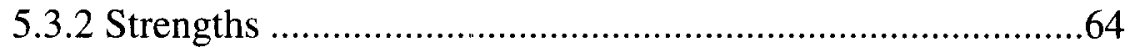

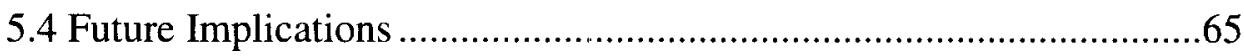

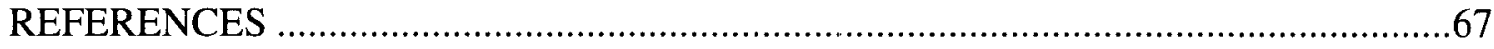

APPENDIX

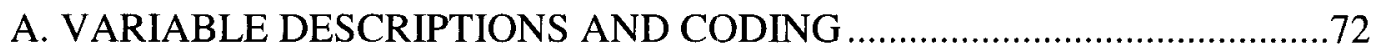

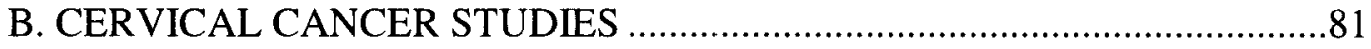

C. SEXUAL HISTORY QUESTIONS AND RESPONSES.........................89

D. TREATMENT OPTIONS BY STAGE OF DISEASE ….........................92

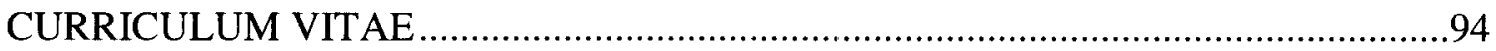




\section{LIST OF TABLES}

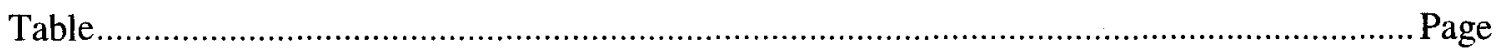

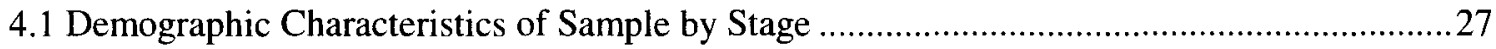

4.2 Physical and Behavioral Characteristics of

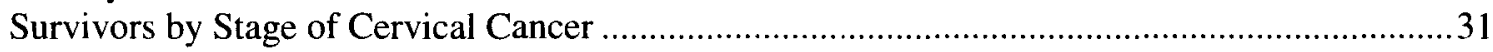

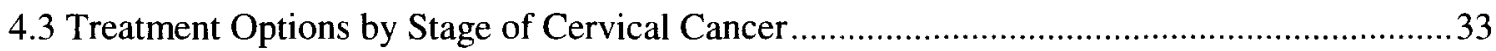

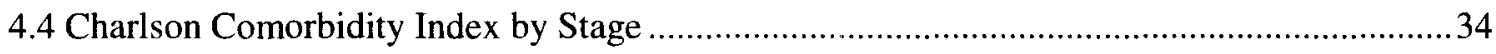

4.5 Self-Reported Quality of Life by Stage of Cervical Cancer................................................ 34

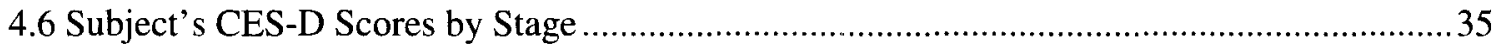

4.7 Effect of Cervical Cancer on Sexual

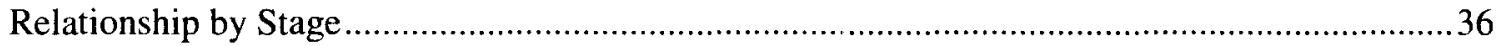

4.8 Univariate Models Describing the Effects

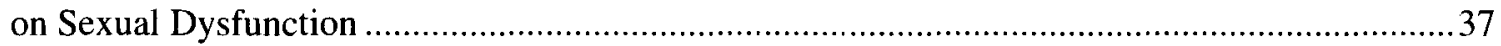

4.9 Models Used to Describe

the Effect of Radiation Therapy on Sexual Dysfunction............................................................41

4.10 Models Used to Describe the

Effect of Stage of Cervical Cancer on Sexual Dysfunction .......................................................43

4.11 Univariate Models Describing the Effects on Depression ..................................................45

4.12 Models Used to Describe the Effect of Stage

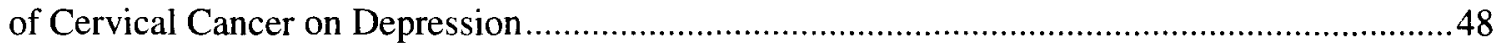

4.13 Univariate Models Describing the Effects on the

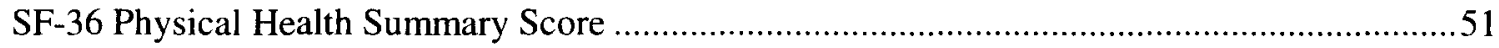

4.14 Models Describing the Effect on

Cervical Cancer Survivor's SF-36 Physical Health Score ......................................................53

4.15 Univariate Models Describing the Effect on the

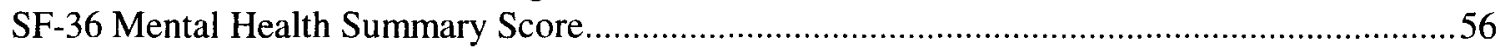

4.16 Models Describing the Effect on

Cervical Cancer Survivor's SF-36 Mental Health Score ….......................................................58 


\section{CHAPTER 1}

\section{INTRODUCTION}

Cervical cancer is characterized as a malignancy in the cervix: the part of the body that connects the uterus to the vagina. (American Society of Clinical Oncology, 2012) A very slow progressing cancer, abnormal cells (that are often eliminated by the body with no treatment) can eventually lead to cervical cancer in patients depending on certain risk factors. It is now established that infection with Human Papilloma Virus (HPV) is causally associated with most cervical cancer diagnoses. (Eifel, Berek \& Thigpen, 2001)

Cervical cancer is one of the most common forms of cancer worldwide with $86 \%$ of cases occurring in the developing world where the age-adjusted incidence rate is 17.8/100,000 cases per year. (World Health Organization, 2010; World Health Organization, 2013) In the U.S, 8.1/100,000 women are diagnosed with cervical cancer every year. This ranks cervical cancer as the $13^{\text {th }}$ leading cancer in all women of North America. (World Health Organization, 2010)

The 2009 prevalence of cervical cancer, in the United States, was 247,711. As of 2012 , it is estimated that 12,170 women will be diagnosed and 4,200 will die from the disease. (Siegel, R., Deepa, N., \& Ahmedin, J., 2012; Howlander et al., 2012) Given that the overall five-year survival rate is $67.9 \%$, the demand for research into cervical disease is high. (Howlander et al., 2012) 
Not only is the burden of disease cause for research, but cervical cancer can affect all areas of a woman's life. In a review of issues surrounding quality of life and cervical cancer survivors, Vistad, Fossa, \& Dahl (2006) define health-related quality of life as the "survivor's self-reported physical, psychosocial, and sexual well-being." This broad definition encompasses many of the problems of cervical cancer survivorship. For example, cervical cancer literature describes all of the following: physical impairments, pain and fatigue, depression, and sexual dysfunction. (Basson, 2005; Bodurka \& Sun, 2006; Goncalves, 2010)

This thesis will examine issues related to the quality of life using data from a cohort of cervical cancer survivors. The primary objective is to determine if a cervical cancer diagnosis and the resulting treatment are associated with a poorer overall quality of life, greater sexual dysfunction and increased depression. In order to accomplish this objective, the study's primary aims are to compare cervical cancer survivors by type of diagnosis, (invasive versus in situ) and treatment type, for differences in overall quality of life, sexual dysfunction and depression. These differences will be quantified using measures such as the MOS 36-Item Short Form Survey (SF-36), Sexual Adjustment Questionnaire (SAQ), and the Center for Epidemiologic Studies Depression (CES-D) Scale while controlling for factors such as age, menopausal status, physical activity, comorbidity, body mass index (BMI), socioeconomic class, tobacco use and alcohol consumption. As a secondary aim the study will seek to determine whether individuals who respond to questions relating to depression using the Charlson Comorbidity Index also score as "depressed" using the CES-D. 


\section{CHAPTER 2}

\section{BACKGROUND}

\subsection{Epidemiology of Cervical Cancer}

\subsubsection{Risk Factors}

Many risk factors are thought to play a role in the development of cervical cancer. For example, multiple sexual partners, tobacco use, immunodeficiency, vitamin A and C deficiencies, contraceptive use, HIV coinfection, coinfection with other sexually transmitted infections, parity, and genetic factors have all been discussed in the literature as increasing risk or promoting the progression of cervical disease. (World Health Organization, 2010; Eifel et al., 2001) However, the major risk factor for cervical cancer is Human papillomavirus (HPV) infection. (Howlander et al., 2012)

According to the Centers for Disease Control and Prevention, HPV is the most common sexually transmitted infection in the United States. It is estimated that 79 million people in the U.S. are infected with one of over 40 different strains of HPV, and 14 million cases will develop each year. (Centers for Disease Control and Prevention, 2012; Centers for Disease Control and Prevention, 2013) The severity of HPV infection ranges from low to high risk. Low risk strains often cause asymptomatic infections that may resolve without treatment and are often the cause of genital warts (strains 6 and 11 cause about $90 \%$ of genital warts). Alternatively, high risk strains are often oncogenic. Currently, twelve oncogenic strains have been identified (strains 16 and 18 are 
responsible for approximately $70 \%$ of cervical cancers). (National Cancer Institute, 2012; Howlander et al., 2012)

\subsubsection{Prevention of Human Papilloma Virus (HPV) Infection}

Since the 1930 's, death rates due to cervical cancer have decreased due to the implementation of routine screening programs. These programs have involved pelvic exams and cytological evaluations in the past, and eventually evolved to include the papanicolaou, or Pap, smear and HPV testing. (Eifel et al., 2001; American Society of Clinical Oncology, 2012) Current cervical cancer prevention efforts are focused on preventing HPV infection through vaccination programs with Gardasil (quadrivalent vaccine) and Cervarix (bivalent) which both protect against HPV strains 16 and 18 (Gardasil also protects against strains 6 and 11). The vaccines are recommended to all preteen girls in an effort to prevent infection before becoming sexually active (Gardasil is also recommended for preteen boys). (Advisory Committee on Immunization Practices [ACIP], 2011) Advisory Committee on Immunization Practices (ACIP) guidelines (2011) also recommend that women through the age of 26 and men through the age of 21 be vaccinated against HPV. (Markowitz et al., 2007)

\subsubsection{Treatment}

The prescribed treatment can be very different from woman to woman, the variation being influenced by many factors. (Eifel et al., 2001; The American Cancer Society, 2012) However, stage of disease is the most influential determinant in the woman's treatment. Women who have in situ disease are often treated with the same

procedures as women who have pre-cancerous changes of the cervix. (The American 
Cancer Society, 2012) However, when women are diagnosed with invasive disease, the treatment options must become more aggressive.

There are four stages of invasive cervical cancer carcinomas and each stage has subcategories. Stage I cervical disease is confined to the cervix and each subcategory is based on invasion depth and tumor size. Stage II carcinomas extend past the cervix but have not infiltrated the pelvic wall. There are two stage II subcategories based on parametrial involvement. Stage III carcinomas have infiltrated the pelvic side wall and involve the lower third of the vagina. There are also two subcategories of stage III. These subcategories are determined by the presence of hydronephrosis or involvement of the lower third of the vagina. Stage IV disease has spread past the true pelvis or involves the bladder and/or rectum, and subcategories are based on the region of the body to which the cancer has spread. (Sobin, Gospodarowicz, \& Wittekind, 2002) According to the American Cancer Society (2012), surgery is a standard treatment in stages I and II. In those stages it can also be combined with internal and external radiation and chemotherapy. (The American Cancer Society, 2012; Eifel et al., 2001) Stage III and IV cancers are treated with radiation and chemotherapy. (The American Cancer Society, 2012; Eifel et al., 2001) For a listing of treatment options by stage see Appendix D.

\subsubsection{Survival}

Incidence and mortality of cervical cancer varies between the developed and developing world. In developing countries, cervical cancer is more common and mortality is higher. (Eifel et al., 2001) In developed countries, where screening programs are more prevalent, rates of cervical cancer and cervical cancer deaths are lower. (Eifel et 
al., 2001) Nonetheless, even worldwide, when mortality is compared to incidence, mortality due to cervical cancer is low. (World Health Organization, 2010)

In the United States, the age-adjusted death rate for cervical cancer patients is 2.4 per 100,000 women. (Howlander et al., 2012) In fact, when invasive disease is caught at its earliest stage, survival is near 100\%. (Bartoces et al., 2009) Therefore, there are an ever growing number of cervical cancer survivors who are faced with the burden of secondary health issues related to their cervical diagnosis and treatment.

\subsection{Quality of Life Issues (Overview)}

Beginning in the mid- $20^{\text {th }}$ century, the World Health Organization started to define health as more than just the absence of disease. (Testa \& Simmonson, 1996) Physical, social, and mental well-being are all vital constructs in identifying an individual's physical or perceived health. Not only are quality of life studies used in the determination of treatment plans for individuals, but they are also used in the planning and development of medical programs and cost analyses. (Testa \& Simmonson, 1996) Therefore, a thorough investigation of the issues surrounding quality of life is necessary in any study of disease.

According to Testa and Simmonson (1996) quality of life can be defined as "The physical, psychological, and social domains of health, seen as distinct areas that are influenced by a person's experiences, beliefs, expectations, and perceptions." These "domains" are measured in two different scales, subjective and objective. Consequently, because of the subjective characteristic of quality of life there are challenges in quantifying quality of life. (Testa \& Simmonson, 1996) 
In the literature, measurement of quality of life varies among researchers. However, most separate the physical, psychological, and social domains and ask specific questions designed to elicit information on each. The answers to these questions are then analyzed in combination with objective factors such as symptoms to evaluate the individual within each domain. (Testa \& Simmonson, 1996) These results are a necessity in a good body of research because the difference that quality of life has on a patient can change the entire course of illness.

Not only has quality of life been recognized by the WHO, but quality of life studies have become particularly important in cancer research. As the number of individuals who survive cancer continues to increase, the need to know what challenges they will face throughout their lifetime increases. (Ferrell, Dow, \& Grant, 1995) Ferrell et al. (1995) give two reasons why quality of life studies have become such a necessity when investigating cancer: the increased number of survivors and the increased awareness of chronic diseases such as cancer.

First, the improvement of treatment plans based on advanced medical technology and more efficient supportive care are major reasons as to why there is an increase in the number of cancer survivors. (Ferrell et al., 1995) However, this often leaves cancer survivors with years of coping with difficult mental, physical, or well-being issues subsequent to their diagnosis and treatment.

Secondly, as the number of cancer survivors grows, the "voice" that survivors have within our communities is increasing. (Ferrell et al., 1995) Cancer survivors provide support through cancer-centered support groups, lobby for the health of others, and may be involved with the publication of materials on their disease. This awareness in the 
community demands more research and change that better informs and supports a cancer survivor.

This combination that Ferrell et al. (1995) studied, has led to a large amount of literature that has sought and discovered many changes that affect quality of life. Specifically in cervical cancer research, mental and physical changes such as depression, self-esteem, body image, relationship changes, spiritual changes, physical differences in the woman's body, and sexual function have been revealed.

The themes of this thesis, sexual dysfunction and overall quality of life, as measured by the Medical Outcomes Study 36-item Short Form Survey (SF-36), are very common themes in the literature. For many women, sexual dysfunction and its involvement in self-image and relationships, is a major priority. Similarly, the change in quality of life that a diagnosis of cervical cancer can have is of major concern. Especially, because the effects of cervical cancer can be faced for decades the woman is considered to be cancer-free.

\subsubsection{Sexual Dysfunction}

Sexual dysfunction is a common quality of life issue among cervical cancer survivors. In a review by Bodurka and Sun (2006) $50 \%$ of women diagnosed with gynecologic cancer were diagnosed with at least one indicator of sexual dysfunction. Treatment regimens and the disease itself can cause physiological changes that make sex difficult after diagnosis, and survival time has also been associated with sexual dysfunction. (Donovan et al., 2007; Frumovitz et al., 2005)

Sexual dysfunction is defined in a variety of way throughout the literature. Many studies use frequency of sexual activity, desire, a feeling of effects on relationships, and 
some use physical changes that lead to effects on sexual health. Most of the sexual dysfunction literature can be divided into two broad topics; psychological or physiological problems.

With regard to the psychological effects of cervical cancer on a woman's sexual health, several problems are associated with cervical cancer survivors. Jensen et al. (2004) found that $85 \%$ of patients, two years post-diagnosis, had no interest in sex. Then in 2007, Donovan et al. found that cervical cancer survivors reported less interest in sex, more sexual dysfunction, and less satisfaction than women without cervical cancer. Furthermore, treatments, including surgery were associated with reduced sexual interest, feelings of negative body image, poor self-confidence, and anxiety about sexual performance. (Jensen et al., 2004; Vrzackova, Weiss, \& Cibula, 2010)

The studies that have chosen to concentrate on the physical changes caused by cervical cancer have found several associations, particularly with treatment. For example, radiation therapy is associated with the physiological effects of stenosis and shortening of the vagina and reduced lubrication. (Abitbol \& Davenport, 1974; Bodurka \& Sun 2006; Donovan et al., 2007) Surgery is associated with anatomical effects such as reduced vaginal wall elasticity, vaginal shortening, and changes in hormone levels. (Vrzackova et al., 2010) These physical changes have then been shown to cause the following problems: reduced sexual desire, dyspareunia (painful intercourse), and the loss of the ability to achieve orgasm, (Donovan et al., 2007; Greenwald \& McCorkle, 2008)

\subsubsection{Assessing the Impact of Diagnosis with the Sexual Adjustment Questionnaire} $(S A Q)$ 
The Sexual Adjustment Questionnaire (SAQ) is a three section, 108-question instrument developed to assess the sexual health of cancer patients. One of its more interesting characteristics, noted by Greenwald and McCorkle (2008), is that the questionnaire seeks to distinguish between sexuality and sexual function.

When the SAQ is utilized in cervical cancer research it is usually not used in its entirety. However, many of the studies that have evaluated sexual dysfunction using the SAQ, report the use of very similar questions. (Greenwald \& McCorkle, 2008; Greimel et al., 2009; Gotay, Farley, Kawamoto, \& Mearig, 2008) In fact, the specific question that asks subjects to rate the effect of cancer on their sexual relationships is almost always asked. The results gathered by the questionnaire, however, are not always so consistent. Greenwald and McCorkle (2008) reported that stage of disease was associated with a negative effect on sexual relationships and that reduced frequency was associated with race. The same year Gotay et al. (2008) found that $44 \%$ of the cervical cancer survivors sampled, reported cervical cancer had a negative impact on their sexual relationships. Alternatively, Griemel et al. (2009) found no significant differences among study groups with regard to sexual activity, pleasure, or discomfort (frequency of sexual activity was found to be significantly less in survivors who were treated with surgery and radiation).

\subsubsection{Assessing Quality of Life with the MOS 36-item Short Form Survey (SF-36)}

The SF-36 is a validated survey tool designed to measure the quality of life of individuals regardless of age, disease, or treatment (higher scores indicate better quality of life). (Ware \& Sherbourne, 1992) This tool, when used in cervical cancer research, evaluates many of the quality of life issues that have been reported by survivors, and has 
been used when comparing study groups. Results have been inconsistent with some studies reporting negative impacts, some positive, and some no impact at all. (Gotay et al., 2008; Bartoces et al., 2009; Wenzel et al., 2005; Frumovitz et al., 2005; Greimel et al., 2009)

Several studies have evaluated quality of life among cervical cancer survivors using the SF-36 and have reported that they appear to have a better or similar quality of life in comparison to study groups. Gotay et al. (2008) sought to investigate the differences in invasive cervical cancer survivors (who were also a part of the military health system) and a national normative sample formed from respondents to the National Health Survey of Functional Health Status and surveys conducted by the National Research Corporation. The researchers reported that cervical cancer survivors have better emotional well-being than comparative groups and that in general the cervical cancer survivors scored similar to the comparative groups in all of the SF-36 subscales. (Gotay et al., 2008) In fact, in this study the only significant difference in quality of life measures was the increased mean for the mental health subscale score measured in cervical cancer survivors. (Gotay et al., 2008)

A similar result was found in the study by Bartoces et al. (2009). In this study, designed to compare women with invasive and noninvasive cancer diagnoses, women in both groups were found to have similar SF-36 Mental and Physical Composite scores. Even after adjusting for demographic and medical information significant differences in mean scores were not found. (Bartoces et al., 2009)

Wenzel et al. (2005) investigated the effects on long-term quality of life in cervical cancer survivors that were of child-bearing age. When cancer survivors (who 
were diagnosed 5-10 years prior) were compared to age- matched controls no significant differences in quality of life were found between the groups. Specifically, when the difference in the mean SF-36 Mental and Physical Health Summary Scores of the cases and controls was compared it did not reach significance. (Wenzel et al., 2005) In fact, survivors were to found to have a higher mean SF-36 Physical Health Summary score than the mean score seen in the normative data. (Wenzel et al., 2005)

Significant deficits in the quality of life of cervical cancer survivors have been reported as well. (Frumovitz et al., 2005; Greimel et al., 2009) In a study by Frumovitz et al. (2005) researchers found that when survivors were grouped according to treatment, compared to each other, and also to a control group (using the SF-12, a subset of the SF36), significant differences were found. (Frumovitz et al., 2005) In this study, women who were treated with radiation were found to have significantly lower mean physical component scores than women treated with only surgery and women in the control group. (Frumovitz et al., 2005)

Although the study by Greimel et al. (2009) did not use the SF-36, significant quality of life differences between treatment groups were found. In this study, instruments similar to the SF-36, The European Organization for Research and Treatment of Cancer (EORTC) Quality of Life Core Questionnaire (EORTC QLQ-C30) and the Cervix Cancer Module (QLQ-CX24) were used to assess the quality of life of participants. Researchers found that women treated with radiation were more likely to suffer from problems relating to physical functioning, role functioning, and cognitive and social functioning than surgical patients. (Greimel et al., 2009) 
The studies described in the above sections and their primary findings are briefly described in Appendix B.

\subsection{Covariates}

Many of the covariates used in the analysis were chosen because of their use in previous studies. Variables such as lifestyle factors (tobacco and alcohol use), age (age at diagnosis and current age), comorbidity, sexual history (number of sexual partners, age at first sexual contact), parity, spirituality, self-esteem, hormone replacement therapy, socioeconomic status, and survival time were previously identified in the literature surrounding cancer (all types and cervical cancer specific), sexual dysfunction, or quality of life. (See Appendix B)

\subsubsection{Depression}

Depression is a significant covariate in studies of sexual dysfunction. (Greenwald \& McCorkle, 2008; Frumovitz et al., 2005; Vistad et al., 2006) The relationship between the outcome and covariate can be very complex and the direction of the relationships is not known. However, depression is commonly measured and used in analytical models as a control.

\subsubsection{Impact of Diagnosis with relation to the Center for Epidemiologic Studies-} Depression (CES-D) Scale

The Center for Epidemiologic Studies Depression (CES-D) Scale is a commonly used tool in identifying depression among two study groups. This scale is a short survey designed to measure self-reported, depressive symptom levels. (Radloff, 1977)

With regard to cervical cancer studies, the CES-D scale has been used often to evaluate depression in participants. For example, Greenwald and McCorkle (2008), 
report the CES-D scale is used as a "correlate of sexual dysfunction." Although depression was not found to be associated with sexual dysfunction in this study, $47.1 \%$ of the sample was scored as "depressed" using the CES-D scale. (Greenwald \&McCorkle, 2008) Interestingly, the large percentage of women who were determined to be depressed (using the CES-D scale) did not all report being depressed. Nearly $80 \%$ of the sample reported being happy nearly all the time. (Greenwald \& McCorkle, 2008; Radloff, 1977) 


\section{CHAPTER 3}

\section{METHODS}

The Adaptation and Quality of Life among Long-Term Cervical Cancer Survivors study was a National Cancer Institute's Surveillance, Epidemiology, and End Results Program (SEER) special study conducted among several SEER sites in the country. The

study was initially proposed to study the differences among cervical cancer survivors by stage of diagnosis and ethnicity. After completion, the study was intended to provide data on long-term survivors in a population where little to none was available. This thesis will focus on analysis of data collected for the New Mexico site.

\subsection{Study Description}

Cervical cancer cases were ascertained through the New Mexico Tumor Registry (NMTR). Women between the ages of 25 and 79, who were residents of New Mexico at the time of diagnosis, were of Hispanic or non-Hispanic white ethnicity, and had been diagnosed with carcinoma in situ or invasive cervical disease between the years 1980 and 1999 were considered to be eligible to participate. A total of 2,016 cases met the eligibility criteria. Letters were sent to a subjects' diagnosing physician (if known) to confirm diagnosis; a total of 1,389 subjects had physicians listed on the NMTR. A refusal (from a physician) was received for only 2 subjects. Patient contact was then initiated for 1,612 potential participants. The patient correspondence included: letters that described the study and a study brochure. The brochure stated the study purpose and 
goals, explained the questionnaire, and explained the function of the tumor registry. Subjects were then given 14 days to refuse participation or to clarify any details of the information that was sent, and also to attempt to learn which addresses were incorrect before the questionnaires were mailed. A total of 195 subjects were found to have incorrect contact information and 4 potential subjects refused to participate. Over a period of 19 months, 1,414 questionnaires were mailed to potential participants. They were given 2-4 weeks to complete and return the questionnaire; if this deadline was not met they were called in an attempt to complete the questionnaire by phone. Out of the questionnaires mailed to subjects, 150 were assumed to not have been received (143 were deemed to have incorrect contact information and seven were deceased) and 1,264 questionnaires were assumed to have reached subjects. There were 197 completed questionnaires used for analysis ( 78 refusals and 989 unreturned).

\subsection{Data Collection}

The clinical data that was collected on subjects, such as diagnosis data, tumor characteristics, and initial treatment, were gathered from the NMTR. At the time of interview, and questionnaire administration, additional data was collected. The questionnaire used was a compilation of the scales of interest; SF-36, CES-D scale, Charlson Comorbidity Index, and Sexual Adjustment Questionnaire, as well as questions that provided the data for the covariates of interest.

\subsubsection{New Mexico Tumor Registry (NMTR)}

The NMTR was utilized in the QOL Cervical Cancer Survivors study to ascertain potential subjects. After potential subjects were ascertained, medical information such as diagnostics, histological information, and demographics was captured from the registry 
and used to build the list of eligible participants. It was also used for the name and address of the diagnosing physician (when available). (Baumgartner, Fetherolf, Wheeler, Hunt, \& Key, 2003)

\subsubsection{Questionnaire}

The New Mexico Community Health Survey, "Quality of Life and Cervical Disease" was the instrument created to collect patient data at the New Mexico Site. It is a combination of various sources and previously used questionnaires. It consists of four sections that record data on a variety of different variables such as diagnosis and treatment of cervical disease, comorbidity, psychological influences on disease, lifestyle information, and sexual history.

\subsubsection{MOS 36-item Short Form Survey (SF-36), Center for Epidemiologic Studies- Depression (CES-D) Scale, and Charlson Comorbidity Index}

The SF-36, CES-D scale and the Charlson Comorbidity Index were used to measure the outcomes or covariates of interest used in this thesis. Each scale includes a series of questions that combine to form a composite score as described below.

\subsubsection{SF-36}

The SF-36 questionnaire is based on a set of 36 questions that captures data related to physical and emotional health. The questions are summarized into a set of eight scales (physical functioning, role-physical, bodily pain, general health, vitality, social functioning, role-emotional, and mental health) which are further summarized into two summary measures (physical health and mental health). The scores for the scales and summary measures range from 1-100, with higher scores indicating better quality of life. Differences in mean scores, of the eight subscales or the two summary measures, can 
also be tabulated to indicate a difference in quality of life among two study groups. (Ware \& Sherbourne, 1992)

Several reports of the SF-36 reliability and validity have shown that it is highly reliable and that its tests of validity are inconsistent. Reliability tests date back to 1993 and consistently measure reliability statistics above 0.70 (the minimum standard). (Tsai, Bayliss, \& Ware, 1997) Several other studies have published reliability statistics that range from 0.80 to $>0.90$ depending on the scale or summary score being analyzed. (McHorney, Ware, Lu, \& Sherbourne, 1994; Ware, Gandek, and the IQOLA Project Group, 1994) With regard to validity, out of the 10 measures, the most valid mental health measures are the Mental Health, Role Emotional, and Social Function scales, and the Mental Component summary measure. For physical measures, Physical Function, Role Physical, and Bodily Pain scales, and the Physical Component summary measure have been found to be most valid. (Ware, n.d.)

For the portion of the analysis that dealt with the quality of life of the subjects, the summary measures for physical health and mental health were used. These outcome variables were analyzed continuously to determine whether other independent variables affected the mean score of physical and/or mental health.

\subsubsection{CES-D}

Depression was investigated using the CES-D scale. This scale was developed as a tool that measures level of depressive symptoms in a population-based study, where the scale would need to be short and answers would be self-reported. (Radloff, 1977) The scale is composed of 20 questions that are designed to detect depressive symptoms and adverse events that may be occurring in an individual's life. It has been validated as a 
tool to detect depression in studies that compare depressed groups to the general population. Tests of reliability and validity yield reliability coefficients of 0.85 or more and validity correlations of 0.40 or more. (Radloff, 1977)

The scores from the CES_D scale range from 0-60 with higher scores indicating an increased number of depressive symptoms. (Radloff, 1977) According to the original paper by Radloff (1977), a score of $\geq 16$ is indicative of depression. Therefore, during analysis subjects' CES_D scores were dichotomized as $\geq 16$ being considered to be depressed and $<16$ being considered as not be depressed.

\subsubsection{Charlson Comorbidity Index}

The Charlson Comorbidity Index was developed to identify the risk of death due to comorbid conditions in longitudinal studies of hospitalized patients. (Charlson, Pompei, Ales, \& MacKenzie, 1987) The approach is a weighted approach that takes into account the number of comorbid conditions as well as the severity of those conditions. (Charlson et al., 1987) Since its development, it has been validated as a tool used in breast cancer research and it was also adapted to be used in combination with International Classification of Diseases, Ninth Revision (ICD-9) codes. (McGregor et al., 2005)

Scores from the Charlson Comorbidity Index can be analyzed continuously from $0-8$ or categorically. When analyzed categorically, subjects' scores are placed into the following risk categories: no risk (0); low risk (1-2); moderate risk (3-4); and high risk (5-8). (Charlson et al., 1987) When analyzing comorbidity as a possible covariate of sexual dysfunction or quality of life, the variable was left as a categorical variable using the cut-points described by the author. 


\subsubsection{Measures of Sexual Dysfunction}

Sexual dysfunction was measured in the questionnaire using the Sexual Adjustment Questionnaire. The SAQ is a 108-question tool developed to evaluate the effect of cancer on a patient's sexuality and sexual function. (Waterhouse \& Metcalfe, 1991; Greenwald \& McCorkle, 2008) The questions are divided into three sections that correspond to relevant time-periods in a cancer patient's life: diagnosis, surgery, and convalescence. (Waterhouse \& Metcalfe, 1986)

Aside from measuring changes based on time, the SAQ also divides the subject's sexual health into sexuality (desire and importance of sex) and function (enjoyment, tension, or frustration). Sexuality and sexual function are similar, but separate dimensions of a sexual relationship. When studying sexual dysfunction, if sexuality and function are not measured carefully, associations between covariates and sexual functioning could be hard to determine. Therefore, separating the two is preferable.

Lastly, the SAQ specifically evaluates the effect of a cancer diagnosis on the subject's sexual relationships. (Waterhouse \& Metcalfe, 1986; Greenwald \& McCorkle, 2008) By asking respondents to rate the impact cancer has had on their sexual relationships researchers are able to measure a self-reported, quality of life difference caused by a cancer.

The reliability of the SAQ has been found to range from 0.67-1. (Greimel et al., 2009) The initial mean reliability for all three sections was found to be 0.67 by Waterhouse and Metcalfe (1986). However, according to Greenwald and McCorkle (2008) the SAQ exhibits high reliability and validity in its revised forms. The developers 
of the questionnaire do cite validity as a problem in prostate and neck cancers.

(Waterhouse \& Metcalfe, 1986)

Only a portion of the Sexual Adjustment Questionnaire (SAQ) was used in the QOL Cervical Cancer Study. Appendix C provides a listing of the SAQ questions included in this study.

Due to the lack of a complete scale used to measure sexual dysfunction, a single question was chosen to be an indicator of the outcome. The question that asked subjects to rate the effect their cervical cancer diagnosis had on their sexual relationship was determined to measure the outcome best and was used as an indicator of sexual dysfunction. The responses to this question were dichotomized with "Very Bad Effect" and "Some Bad Effect" being pooled to indicate dysfunction, and "No effect," "Some Good Effect," and "Very Good Effect" pooled to indicate a lack of dysfunction. All subjects who reported "no partner" were excluded from analysis.

The covariates age, menopausal status, physical activity, depression, comorbidity, BMI, socioeconomic class, tobacco use and alcohol consumption were also measured. For a complete listing of variables used see Appendix A.

\subsection{Statistical Plan}

The goal of this thesis is to determine if cervical cancer survivors differ in quality of life, sexual functioning and depression by type of diagnosis and treatment. The four $a$ priori hypotheses are as follows:

1. Women diagnosed with cervical cancer who are treated with radiation will report more sexual dysfunction than women receiving other forms of treatment (surgery 
and chemotherapy), controlling for: age, menopausal status, physical activity, depression, comorbidity, BMI, and insurance status.

2. Women diagnosed with invasive cervical cancer will be more likely to suffer from sexual dysfunction than those diagnosed with carcinoma in situ, controlling for; age, menopausal status, physical activity, depression, comorbidity, BMI, and insurance status.

3. Women diagnosed with invasive cervical cancer will be more likely to be depressed as measured by the CES_D than the women diagnosed with carcinoma in situ, controlling for; comorbidity, smoking, alcohol consumption, fatigue, physical activity, BMI, SES and sexual dysfunction.

4. Women who report more sexual dysfunction and depression will have a lower overall quality of life as measured by the SF-36 controlling for comorbidity, smoking, alcohol consumption, physical activity, BMI, and SES.

Based on the secondary aim the hypothesis is as follows:

1. Women who report they suffer from depression (when measured as comorbidity) will also be depressed based on the CES-D scale.

\subsubsection{Logistic Regression Models}

In order to evaluate the relationships between sexual dysfunction, radiation therapy, and stage of disease (hypotheses 1-3), a logistic regression model was created and analyzed using SAS version 9.3. Each model was initially adjusted for age, socioeconomic factors (ethnicity, income, and education), and the other covariates listed in each hypothesis. Radiation and stage of disease were analyzed as dichotomous variables (i.e., did or did not have radiation therapy, invasive or in situ disease). Each 
covariate was categorized based on its distribution within the study population. Age and BMI were considered as both continuous and categorical variables throughout the model building process.

\subsubsection{Linear Regression Model}

In order to evaluate the relationship between quality of life, sexual dysfunction, and depression (hypothesis 4) a generalized linear model was created and analyzed using SAS version 9.3. This model was initially adjusted for age, socioeconomic status (ethnicity, income, and education), and the covariates listed in the hypothesis.

As was described above, the SF-36 summary measures were analyzed continuously. Sexual dysfunction and depression were analyzed as dichotomous variables using the same methods as the logistic regression models. BMI and age were considered as continuous and categorical variables to identify if there was a difference in the analysis. The remaining covariates listed in the hypothesis were initially analyzed using the categories set forth by the questionnaire. Changes were made to the categories through the model-building process. However, Table 4.14 and 4.16 depict the final models used for the SF-36 summary measures and the categorization (if any).

\subsection{Power}

There were two types of analyses completed in this thesis: logistic regression (for estimating odds ratios) and linear regression (for estimating correlations $\left(\mathrm{R}^{2}\right)$. Since the data was previously collected, sample sizes were fixed. In order to evaluate statistical power estimates of the minimum detectable effect size were calculated based on the sample size and exposure frequencies for the type of analysis. These calculations were completed using the free online software, Open Epi (http://www.openepi.com ). 


\subsubsection{Logistic Regression Models}

Open Epi cites Schlesselman's sample size equation as the way in which the minimum detectable odds ratio in logistic regression models are estimated.

(Schlesselman, 1982; Schlesselman, 1974) This standard equation estimates sample sizes in a case-control study given assumptions for exposure frequencies, statistical power $\left(Z_{b}\right)$, and significance level $\left(\mathrm{Z}_{\mathrm{a}}\right)$. If the equation is rearranged, it can then be used to solve for effect sizes. Therefore, using Open Epi the minimum detectable effect estimate for $80 \%$ power can be determined.

The number of subjects for the first two hypotheses (associations between sexual dysfunction and stage of disease and between sexual dysfunction and treatment) was very similar. Therefore, to evaluate power, data from the logistic model that analyzed the association between sexual dysfunction and stage of disease was used. In this model, 51 women were considered to have sexual dysfunction (cases) and 115 women were considered to be without dysfunction (controls). Given these sample sizes, there is $80 \%$ power to consider $(O R \geq 2.7)$ and be statistically significant (at $\mathrm{p} \leq 0.05)$.

To determine the power involved in the logistic model for the third hypothesis (association between stage of disease and depression), 62 women were considered to be depressed (cases) and 129 women were considered to not be depressed (controls). Given these sample sizes, there is $80 \%$ power to consider OR $\geq 2.5$ to be significant (at $p \leq 0.05$ ).

\subsubsection{Linear Regression Models}

Continuous data or interval scale data were utilized in the linear regression models to analyze hypothesis four (the association between sexual dysfunction and quality of life). These models were based on sample sizes that ranged from 156 to 163 
subjects (depending on missing data). Using Cohen's tables, correlation coefficients

$\geq 0.20$, or $\mathbf{R}^{2} \geq 4 \%$, at $80 \%$ ( $\mathrm{p} \leq 0.05$ ) statistical power may be considered. (Cohen, 1988) 


\section{CHAPTER 4}

\section{RESULTS}

\subsection{Descriptive Characteristics of the Sample}

\subsubsection{Demographics}

The mean age of the sample, at the time of interview, was 51 (SD 9.1) and the mean age of the sample, at diagnosis, was 41 (SD 9.2). Approximately $68 \%$ of the women were Non-Hispanic White women; $26 \%$ were Hispanic and 5\% self-reported as "Other" ethnicity (Asian/Pacific Islander, American Indian/Alaska Native, Other). A majority of the women were married or cohabitating at time of diagnosis $(70.1 \%)$ and interview (66.5\%). Approximately $33 \%$ of the women had some college or technical school at diagnosis $(37.1 \%)$ and at the time of interview (37\%), and most had insurance $(82.7 \%)$. Women who reported to have a current income of greater than $\$ 50,000$ at the time of interview composed the biggest income level $(29.4 \%)$. This was not the case at the time of diagnosis. At time of diagnosis, $24.9 \%$ of women reported to have an annual income of between $\$ 15,000$ and $\$ 29,000$. Table 4.1 presents these characteristics for the sample as well as the characteristics stratified by stage of disease. (There were no significant differences between in situ and invasive survivors based on demographic characteristics). 


\subsection{Demographic Characteristics of Sample by Stage}

\begin{tabular}{|c|c|c|c|c|c|c|c|c|}
\hline \multirow[t]{2}{*}{ Variable } & \multicolumn{2}{|c|}{$\begin{array}{c}\text { All } \\
\text { Women }\end{array}$} & \multicolumn{2}{|c|}{$\begin{array}{c}\text { Invasive } \\
(n=94)\end{array}$} & \multicolumn{2}{|c|}{$\begin{array}{c}\text { in situ } \\
(n=101)\end{array}$} & \multicolumn{2}{|c|}{ Chi-Square $/ p^{\mathrm{a}}$} \\
\hline & No. & $\%$ & No. & $\%$ & No. & $\%$ & Chi-Square & $p$ \\
\hline Age, diagnosis & & & & & & & $<0.02$ & 0.9 \\
\hline$<30$ & 14 & 7.1 & 9 & 9.6 & 5 & 5 & & \\
\hline $30-39$ & 81 & 41.1 & 35 & 37.2 & 45 & 44.6 & & \\
\hline $40-49$ & 67 & 34 & 33 & 35.1 & 34 & 33.7 & & \\
\hline $50-59$ & 27 & 13.7 & 12 & 12.8 & 14 & 13.9 & & \\
\hline $60-69$ & 8 & 4.1 & 5 & 5.3 & 3 & 3 & & \\
\hline Age, current & & & & & & & 3.8 & 0.5 \\
\hline$<40$ & 16 & 8.1 & 5 & 5.3 & 11 & 10.9 & & \\
\hline $40-49$ & 71 & 36 & 33 & 35.1 & 37 & 36.6 & & \\
\hline $50-59$ & 70 & 35.5 & 30 & 31.9 & 40 & 39.6 & & \\
\hline$>60$ & 38 & 19.3 & 24 & 25.5 & 13 & 12.9 & & \\
\hline Missing & 2 & 1 & 2 & 2.1 & - & - & & \\
\hline Marital Status, diagnosis & & & & & & & 3.3 & 0.1 \\
\hline Married or Cohabitating & 138 & 70.1 & 71 & 75.5 & 65 & 64.4 & & \\
\hline Not Married & 58 & 29.4 & 22 & 23.4 & 36 & 35.6 & & \\
\hline Missing & 1 & 0.5 & 1 & 1.1 & - & - & & \\
\hline Marital Status, current & & & & & & & 0.7 & 0.4 \\
\hline
\end{tabular}




\begin{tabular}{|c|c|c|c|c|c|c|c|c|}
\hline Married or Cohabitating & 131 & 66.5 & 59 & 62.8 & 70 & 69.3 & & \\
\hline Not Married & 65 & 33 & 34 & 36.2 & 31 & 30.7 & & \\
\hline Missing & 1 & 0.5 & 1 & 0.5 & - & - & & \\
\hline Education, diagnosis & & & & & & & 3.3 & 0.1 \\
\hline High school graduate or Less & 67 & 34 & 38 & 40.4 & 28 & 27.7 & & \\
\hline Some college or technical school & 73 & 37.1 & 34 & 36.2 & 39 & 38.6 & & \\
\hline College graduate & 29 & 14.7 & 10 & 10.6 & 18 & 17.8 & & \\
\hline Graduate school & 26 & 13.2 & 11 & 11.7 & 15 & 14.9 & & \\
\hline Missing & 2 & 1 & 1 & 1.1 & 1 & 1 & & \\
\hline Education, current & & & & & & & 2.8 & 0.1 \\
\hline High school graduate or Less & 47 & 24.1 & 27 & 28.7 & 20 & 19.8 & & \\
\hline Some college or technical school & 72 & 36.9 & 36 & 38.3 & 36 & 35.6 & & \\
\hline College graduate & 38 & 19.5 & 16 & 17 & 22 & 21.9 & & \\
\hline Graduate school & 32 & 16.4 & 13 & 13.8 & 19 & 18.8 & & \\
\hline Missing & 6 & 3.1 & 2 & 2.1 & 4 & 4 & & \\
\hline Income, diagnosis & & & & & & & 0.5 & 0.5 \\
\hline$<\$ 14,999$ & 47 & 23.9 & 27 & 28.7 & 19 & 18.8 & & \\
\hline$\$ 15,000-\$ 29,999$ & 49 & 24.9 & 18 & 19.2 & 31 & 30.7 & & \\
\hline$\$ 30,000-\$ 39,999$ & 36 & 18.3 & 20 & 21.3 & 15 & 14.9 & & \\
\hline$\$ 50,000$ or more & 36 & 18.3 & 16 & 17 & 20 & 19.8 & & \\
\hline
\end{tabular}




\begin{tabular}{|c|c|c|c|c|c|c|c|c|}
\hline Unknown/Missing/Refused & 29 & 14.7 & 13 & 13.8 & 16 & 15.8 & & \\
\hline Income, current & & & & & & & 0.4 & 0.5 \\
\hline$<\$ 14,999$ & 32 & 16.2 & 15 & 16 & 16 & 15.8 & & \\
\hline$\$ 15,000-\$ 29,999$ & 42 & 21.3 & 24 & 25.3 & 18 & 17.8 & & \\
\hline$\$ 30,000-\$ 39,999$ & 36 & 18.3 & 17 & 18.1 & 19 & 18.8 & & \\
\hline$\$ 50,000$ or more & 58 & 29.4 & 26 & 27.7 & 31 & 30.7 & & \\
\hline Unknown/Missing/Refused & 29 & 14.7 & 12 & 12.8 & 17 & 16.8 & & \\
\hline Ethnicity & & & & & & & 0.1 & 0.8 \\
\hline Non-Hispanic, white & 133 & 67.5 & 65 & 69.2 & 67 & 66.3 & & \\
\hline Hispanic & 51 & 25.9 & 20 & 21.3 & 30 & 30 & & \\
\hline Other & 10 & 5.1 & 6 & 6.4 & 4 & 4 & & \\
\hline Missing & 3 & 1.5 & 3 & 3.2 & - & - & & \\
\hline Insurance, current & & & & & & & 0.3 & 0.6 \\
\hline Yes & 163 & 82.7 & 78 & 83 & 83 & 82.2 & & \\
\hline No & 28 & 14.2 & 12 & 12.8 & 16 & 15.8 & & \\
\hline Missing & 6 & 3.1 & 4 & 4.3 & 2 & 2 & & \\
\hline
\end{tabular}




\subsubsection{Behavioral and Physical Characteristics}

The mean, BMI (at the time of the interview) of the study population was 27.8 (SD 6.6). The mean BMI at diagnosis was 25.0 (SD 6.4). Subjects were also categorized into three groups using the World Health Organization's BMI cut points for normal (18.5-24.99), overweight (25-29.99), and obese ( $\geq 30)$ individuals. (World Health Organization, 2006) At diagnosis $53 \%$ of women had a BMI of $<25$ and at time of interview $37.1 \%$ had a BMI of $<25$. At the time of diagnosis most women were still having periods or were in menopause $(81.2 \%)$. Then at the time of interview most women were no longer having periods or were post-menopausal (71.1\%).

The majority of women reported to have participated in at least one form of physical activity in the past month (75.4\%). A majority of subjects also reported to have had at least one alcoholic beverage in the past month $(54.8 \%)$ and to have smoked at least 100 cigarettes in their lifetime $(58.9 \%)$.

Table 4.2 shows the physical and behavioral characteristics of the sample. Most of characteristics did not any significant associations when compared by stage of cervical cancer. However, the women's menstrual status at the time of interview was found to be associated by stage, $\left(X^{2}=23.4 p<0.01\right)$. 
Table 4.2 Physical and Behavioral Characteristics of Survivors by Stage of Cervical Cancer

\begin{tabular}{|c|c|c|c|c|c|c|c|c|}
\hline \multirow[t]{2}{*}{ Variable } & \multicolumn{2}{|c|}{$\begin{array}{c}\text { All } \\
\text { Women }\end{array}$} & \multicolumn{2}{|c|}{$\begin{array}{c}\text { Invasive } \\
(n=94) \\
\end{array}$} & \multicolumn{2}{|c|}{$\begin{array}{c}\text { in situ } \\
(n=101)\end{array}$} & \multicolumn{2}{|c|}{ Chi-Square/ $p^{a}$} \\
\hline & No. & $\%$ & No. & $\%$ & No. & $\%$ & Chi-Square & $p$ \\
\hline Menstrual Status, diagnosis & & & & & & & 1.3 & 0.3 \\
\hline Having periods or in menopause & 160 & 81.2 & 75 & 79.8 & 83 & 82.2 & & \\
\hline $\begin{array}{l}\text { No longer having periods or post- } \\
\text { menopausal }\end{array}$ & 27 & 13.7 & 16 & 8.217 & 11 & 10.9 & & \\
\hline Don't know or missing & 10 & 5.1 & 3 & 3.2 & 7 & 6.9 & & \\
\hline Menstrual Status, current & & & & & & & 23.5 & $<0.01$ \\
\hline Having periods or in menopause & 50 & 25.4 & 9 & 9.6 & 39 & 38.6 & & \\
\hline $\begin{array}{l}\text { No longer having periods or post- } \\
\text { menopausal }\end{array}$ & 140 & 71.1 & 83 & 88.3 & 57 & 56.4 & & \\
\hline Don't know or missing & 7 & 3.6 & 2 & 2.1 & 5 & 5 & & \\
\hline Physical Activity & & & & & & & 0.3 & 0.6 \\
\hline Physical activity, past month & 147 & 75.4 & 68 & 72.3 & 79 & 78.2 & & \\
\hline No physical activity, past month & 45 & 23.1 & 23 & 24.5 & 22 & 21.9 & & \\
\hline Missing or Refused & 3 & 1.5 & 3 & 3.2 & - & - & & \\
\hline BMI, diagnosis & & & & & & & 0.2 & 0.6 \\
\hline Less than 25 & 105 & 53.3 & 53 & 56.4 & 50 & 49.5 & & \\
\hline $25-29$ & 35 & 17.8 & 16 & 17 & 19 & 18.8 & & \\
\hline 30 or more & 25 & 12.7 & 12 & 12.8 & 13 & 12.9 & & \\
\hline Missing & 32 & 16.2 & 13 & 13.8 & 19 & 18.8 & & \\
\hline
\end{tabular}




\begin{tabular}{|c|c|c|c|c|c|c|c|c|}
\hline BMI, current & & & & & & & $<0.01$ & 1.0 \\
\hline Less than 25 & 73 & 37.1 & 35 & 37.2 & 37 & 36.6 & & \\
\hline $25-29$ & 58 & 29.4 & 27 & 28.7 & 30 & 29.7 & & \\
\hline 30 or more & 59 & 30 & 29 & 49.2 & 30 & 29.7 & & \\
\hline Missing & 7 & 3.6 & 3 & 3.2 & 4 & 4 & & \\
\hline Alcohol Consumption & & & & & & & 0.4 & 0.6 \\
\hline $1+$, past month & 108 & 54.8 & 50 & 53.2 & 58 & 57.4 & & \\
\hline None, past month & 87 & 44.2 & 43 & 45.7 & 42 & 41.6 & & \\
\hline Missing & 2 & 1.0 & 1 & 1.1 & 1 & 1 & & \\
\hline Smoking status, lifetime & & & & & & & 0.2 & 0.7 \\
\hline Ever Smoked & 116 & 58.9 & 57 & 60.6 & 59 & 58.4 & & \\
\hline Never Smoked & 80 & 40.6 & 36 & 38.3 & 42 & 41.6 & & \\
\hline Missing & 1 & 0.5 & 1 & 1.1 & - & - & & \\
\hline Smoking status, current & & & & & & & 2.4 & 0.1 \\
\hline Smoke every day & 43 & 21.8 & 26 & 27.7 & 17 & 16.8 & & \\
\hline Smoke some days & 9 & 4.6 & 3 & 3.2 & 6 & 5.9 & & \\
\hline Never smoked & 63 & 32 & 28 & 29.8 & 35 & 34.7 & & \\
\hline Missing & 82 & 42 & 37 & 39.4 & 43 & 42.6 & & \\
\hline
\end{tabular}

${ }^{\mathrm{a}} n=2$ unstaged; excluded from analysis 


\subsubsection{Other Covariates of Interest}

Data collected on treatment options described $91 \%$ percent of the sample as having had some form of surgery to treat their disease, $15 \%$ of the subjects having received radiation therapy, and $2 \%$ of the sample received chemotherapy for their cancer. When the treatment forms were compared by stage of disease, radiation therapy was found to be significantly associated $\left(\mathrm{X}^{2}=36.84 p<.01\right)$. Table 4.3 represents the forms of treatment for all subjects as well as treatment stratified by stage of cervical cancer.

\section{Table 4.3 Treatment Options by Stage of Cervical Cancer}

\begin{tabular}{|c|c|c|c|c|c|c|c|c|}
\hline \multirow[t]{2}{*}{ Variable } & \multicolumn{2}{|c|}{$\begin{array}{c}\text { All } \\
\text { Women }\end{array}$} & \multicolumn{2}{|c|}{$\begin{array}{c}\text { Invasive } \\
(n=94)\end{array}$} & \multicolumn{2}{|c|}{$\begin{array}{c}\text { in situ } \\
(n=101)\end{array}$} & \multicolumn{2}{|c|}{ Chi-Square/ $p^{\mathrm{a}}$} \\
\hline & No. & $\%$ & No. & $\%$ & No. & $\%$ & Chi-Square & $p$ \\
\hline Surgery & & & & & & & 2.9 & 0.1 \\
\hline Yes & 180 & 91.4 & 83 & 88.3 & 96 & 95 & & \\
\hline $\mathrm{No}^{b}$ & 17 & 8.6 & 11 & 11.7 & 5 & 5 & & \\
\hline Missing & - & - & - & - & - & - & & \\
\hline Radiation & & & & & & & 36.8 & $<0.01$ \\
\hline No Radiation & 166 & 84.3 & 64 & 68.1 & 101 & 100 & & \\
\hline Radiation given & 30 & 15.2 & 29 & 30.9 & - & - & & \\
\hline Missing/Unknown & 1 & 0.5 & 1 & 0.5 & - & - & & \\
\hline Chemotherapy & & & & & & & 4.4 & 0.05 \\
\hline No Chemotherapy & 192 & 97.5 & 89 & 94.7 & 101 & 100 & & \\
\hline Chemotherapy $^{\mathrm{c}}$ & 4 & 2 & 4 & 4.3 & - & - & & \\
\hline Missing/Refused & 1 & 0.5 & 1 & 1.1 & - & - & & \\
\hline
\end{tabular}

${ }^{\mathrm{a}} n=2$ unstaged; excluded from analysis

${ }^{b}$ No surgery based on surgery not recommended as $1^{\text {st }}$ course treatment $(n=3)$ or surgery recommended but not as $1^{\text {st }}$ course treatment $(n=14)$

${ }^{\mathrm{c}}$ Single or multiple agents

The majority of women with data on comorbidity were scored as zero or "No Risk" by the Charlson Comorbidity Index (67.5\%). Table 4.4 shows the distribution of the sample with regard to the Charlson Comorbidity Index as well as the index stratified 
by stage of cervical cancer. There was not a significant difference between the two stages.

Table 4.4 Charlson Comorbidity Index by Stage

\begin{tabular}{lcccccccc} 
Variable & \multicolumn{2}{c}{$\begin{array}{c}\text { All } \\
\text { Women }\end{array}$} & \multicolumn{2}{c}{$\begin{array}{c}\text { Invasive } \\
(n=94)\end{array}$} & \multicolumn{2}{c}{$\begin{array}{c}\text { in situ } \\
(n=101)\end{array}$} & \multicolumn{2}{c}{${\text { Chi-Square/ } \mathbf{p}^{\mathbf{a}}}^{2}$} \\
& No. & $\%$ & No. & $\%$ & No. & $\%$ & Chi-Square & $p$ \\
\hline $\begin{array}{l}\text { Charlson Comorbidity } \\
\text { Index } \\
\quad \text { No Risk (0) }\end{array}$ & 133 & 67.5 & 61 & 64.9 & 71 & 70.3 & & 0.1 \\
Low Risk (1-2) & 48 & 24.4 & 23 & 24.5 & 24 & 24 & & \\
Moderate Risk (3-4) & 4 & 2. & 3 & 3.2 & 1 & 1 & & \\
High Risk (5-8) & 5 & 2.5 & 4 & 4.3 & 1 & 1 & & \\
Missing & 7 & 3.6 & 3 & 3.2 & 4 & 4 & & \\
\hline
\end{tabular}

$\bar{a}_{n=2}$ unstaged; excluded from analysis

Subjects were also asked to rate their quality of life at two different time periods:

2 years post-diagnosis and at the time of the interview. Many of the women responded that their quality of life was "Excellent" two years post-diagnosis (33.5\%) and at the time of the interview (33\%). A significant association was found when the survivors were stratified by stage $\left(\chi^{2}=9.2 p<0.01\right)$. Table 4.5 represents the responses to the selfreported quality of life questions as well as those responses stratified by stage.

Table 4.5 Self-Reported Ouality of Life by Stage of Cervical Cancer

\begin{tabular}{|c|c|c|c|c|c|c|c|c|}
\hline \multirow[t]{2}{*}{ Variable } & \multicolumn{2}{|c|}{$\begin{array}{c}\text { All } \\
\text { Women }\end{array}$} & \multicolumn{2}{|c|}{$\begin{array}{c}\text { Invasive } \\
(n=94) \\
\end{array}$} & \multicolumn{2}{|c|}{$\begin{array}{c}\text { in situ } \\
(n=101)\end{array}$} & \multicolumn{2}{|c|}{ Chi-Square/pa } \\
\hline & No. & $\%$ & No. & $\%$ & No. & $\%$ & Chi-Square & $p$ \\
\hline $\begin{array}{l}\text { Self-reported QOL, } \\
2 \text { years post- } \\
\text { diagnosis }\end{array}$ & & & & & & & 9.2 & $<0.01$ \\
\hline Excellent & 66 & 33.5 & 24 & 25.5 & 42 & 41.6 & & \\
\hline Very Good & 54 & 27.4 & 24 & 25.5 & 29 & 28.7 & & \\
\hline Good & 51 & 25.9 & 28 & 29.8 & 22 & 21.8 & & \\
\hline Fair/Poor & 23 & 11.7 & 16 & 17 & 7 & 6.9 & & \\
\hline Missing & 3 & 1.5 & 2 & 2 & 1 & 1 & & \\
\hline
\end{tabular}




\begin{tabular}{lcccccccc}
\hline $\begin{array}{l}\text { Self-reported QOL, } \\
\text { current }\end{array} \quad$ & & & & & & 2.6 & 0.1 \\
Excellent & 65 & 33 & 25 & 26.6 & 40 & 39.6 & & \\
Very Good & 58 & 29.4 & 31 & 33 & 26 & 25.7 & & \\
Good & 40 & 20.3 & 17 & 18.1 & 22 & 21.8 & & \\
Fair/Poor & 30 & 15.2 & 18 & 19.2 & 12 & 11.9 & \\
$\quad$ Missing & 4 & 2 & 3 & 3.2 & 1 & 1 & & \\
\hline${ }_{n=2}$ & & & & & & &
\end{tabular}

\subsubsection{Outcome Variables}

Depression, as measured by the CES-D scale, was found to occur in $32 \%$ of the sample when dichotomized ("depressed" $(\geq 16)$ and "not depressed" $(<16))$. No significant differences were found when comparing in situ and invasive groups. See Table 4.6 for the distribution of depression in the sample and among in situ and invasive groups.

\section{Table 4.6 Subjects CES-D Scores by Stage}

\begin{tabular}{lcccccccc} 
Variable & \multicolumn{2}{c}{$\begin{array}{c}\text { All } \\
\text { Women }\end{array}$} & \multicolumn{2}{c}{$\begin{array}{c}\text { Invasive } \\
(n=94)\end{array}$} & \multicolumn{2}{c}{$\begin{array}{c}\text { in situ } \\
(n=101)\end{array}$} & \multicolumn{2}{c}{${\text { Chi-Square/ } \boldsymbol{p}^{\mathbf{a}}}^{2}$} \\
\hline & No. & $\%$ & No. & $\%$ & No. & $\%$ & Chi-Square & $p$ \\
\hline CES-D Scale & & & & & & & 0.1 & 0.7 \\
Score of $<16$ & 130 & 66 & 61 & 64.9 & 68 & 67.3 & & \\
Score of $\geq 16$ & 63 & 32 & 31 & 33 & 31 & 30.7 & & \\
Missing & 4 & 2 & 2 & 2.1 & 2 & 2 & & \\
\hline
\end{tabular}

${ }_{n=2}$ unstaged; excluded from analysis

With regard to the sexual history questions answered in the questionnaire, very few responses were missing from the dataset. However, many women indicated there was "No Sexual Activity" or "Partner" in their life. For the 8 questions, percentages for "no partner" or "no sexual activity" ranged from a minimum of $14.7 \%-26 \%$ and subjects were excluded from the analysis. 
The majority of women $(91 \%)$ indicated they had an overall positive or negative sexual history among all the sexual history questions. Fifty-sex percent of women responded to all 8 sexual history questions with negative responses (i.e. Sex is "of no importance" or only "slightly important" or desire for sexual activity "Never" or "Almost Never"). Appendix C represents the frequencies of the responses to all 8 sexual history questions and the frequencies of the composite variable.

The responses to the sexual dysfunction indicator $(n=166)$ showed that many women felt their diagnosis had no effect on their sexual relationship with their partner (58.4\%). However, only approximately $9 \%$ felt it had a positive effect ("some good" or "very good" effect), and approximately $26 \%$ felt it had a negative effect ("very bad" or "some bad" effect). Table 4.7 represents the distribution for the subjects' responses to the sexual dysfunction indicator as well as the indicator stratified by stage of disease.

\section{Table 4.7 Effect of Cervical Cancer on Sexual Relationship by Stage}

\begin{tabular}{|c|c|c|c|c|c|c|c|c|}
\hline \multirow[t]{2}{*}{ Variable } & \multicolumn{2}{|c|}{$\begin{array}{c}\text { All } \\
\text { Women }\end{array}$} & \multicolumn{2}{|c|}{$\begin{array}{c}\text { Invasive } \\
(n=94)\end{array}$} & \multicolumn{2}{|c|}{$\begin{array}{c}\text { in situ } \\
(n=101)\end{array}$} & \multicolumn{2}{|c|}{ Chi-Square/p $p^{a}$} \\
\hline & No. & $\%$ & No. & $\%$ & No. & $\%$ & Chi-Square & $\bar{p}$ \\
\hline $\begin{array}{l}\text { Effect on } \\
\text { Sexual Relationship }\end{array}$ & & & & & & & 12.7 & $<0.01$ \\
\hline $\begin{array}{l}\text { Very Bad/ } \\
\text { Some Bad effect }\end{array}$ & 51 & 25.9 & 34 & 36.2 & 16 & 15.8 & & \\
\hline $\begin{array}{l}\text { No effect/Some } \\
\text { Good/ } \\
\text { Very Good Effect }\end{array}$ & 115 & 58.4 & 43 & 45.7 & 71 & 70.3 & & \\
\hline $\begin{array}{l}\text { Missing or No } \\
\text { partner }\end{array}$ & 31 & 15.7 & 17 & 18.1 & 14 & 13.9 & & \\
\hline
\end{tabular}

The range of scores for the SF-36 Physical and Mental Health Summary Scores

was 2-100. The mean Physical Health Summary Score of the sample ( $n=192)$ was 74.01 (SD 22.4) and the mean Mental Health Summary Score was 68.80 (SD 21.8)

\subsubsection{Secondary Aim}


The concordance between self-reported depression (measured by the Charlson Comorbidity Index) and depression (measured by the CES-D scale) was found to be significant $\left(\mathrm{X}^{2}=27.5, \mathrm{p}<0.01\right)$.

\subsection{Sexual Dysfunction, Stage of Disease, and Radiation Therapy}

Univariate analysis was used to evaluate if any variables were significantly associated with sexual dysfunction (Table 4.8). Radiation therapy, stage of disease, and depression were significant at the $(p<0.05)$ level. All other covariates were not significant.

Table 4.8 Univariate Models Describing the Effects on Sexual Dysfunction ${ }^{\mathrm{a}}$

\begin{tabular}{|c|c|c|c|c|}
\hline Variable Name & Odds Ratio & Beta & $p$ & $n$ \\
\hline Radiation Therapy & 3.7 & 1.3 & $<0.01$ & 165 \\
\hline Stage & 3.5 & 1.3 & $<0.01$ & 164 \\
\hline Depression $^{b}$ & 3.3 & 1.2 & $<0.01$ & 166 \\
\hline Age, current ${ }^{c}$ & 1.0 & $<-0.01$ & 0.9 & 165 \\
\hline Age, diagnosis ${ }^{c}$ & 1.0 & $<-0.01$ & 0.8 & 166 \\
\hline Ethnicity & & & & 164 \\
\hline Other & 2.4 & 0.9 & 0.2 & \\
\hline Hispanic & 0.9 & -0.1 & 0.8 & \\
\hline White, Non-Hispanic ${ }^{d}$ & - & - & - & \\
\hline Education, current & & & & 163 \\
\hline HS graduate or less & 1.5 & 0.4 & 0.5 & \\
\hline Some college & 1.7 & 0.5 & 0.3 & \\
\hline College graduate & 0.9 & -0.1 & 0.9 & \\
\hline Graduate school $^{\mathrm{d}}$ & - & - & - & \\
\hline Education, diagnosis & & & & 166 \\
\hline HS graduate or less & 1.3 & 0.3 & 0.6 & \\
\hline Some college & 1.5 & 0.4 & 0.5 & \\
\hline
\end{tabular}




\begin{tabular}{|c|c|c|c|c|}
\hline College graduate & 0.7 & -0.4 & 0.6 & \\
\hline Graduate school $^{\mathrm{d}}$ & - & - & - & \\
\hline Income, current & & & & 144 \\
\hline$<\$ 10,000-\$ 14,999$ & 2.3 & 0.8 & 0.1 & \\
\hline$\$ 15,000-\$ 29,999$ & 0.9 & -0.02 & 1 & \\
\hline$\$ 30,000-\$ 39,999$ & 1.6 & 0.5 & 0.3 & \\
\hline$>\$ 50,000^{\mathrm{d}}$ & - & - & - & \\
\hline Income, diagnosis & & & & 144 \\
\hline$<\$ 10,000-\$ 14,999$ & 2.4 & 0.9 & 0.1 & \\
\hline$\$ 15,000-\$ 29,999^{d}$ & - & - & - & \\
\hline$\$ 30,000-\$ 39,999$ & 1.9 & 0.6 & 0.2 & \\
\hline$>\$ 50,000$ & 1.6 & 0.4 & 0.4 & \\
\hline Charlson Comorbidity Index ${ }^{e}$ & & & & 164 \\
\hline High Risk & 3.7 & 1.3 & 0.7 & \\
\hline Moderate Risk & 7.4 & 2 & 0.9 & \\
\hline Low Risk & 0.9 & -0.1 & 0.8 & \\
\hline No Risk ${ }^{d}$ & - & - & - & \\
\hline BMI, current ${ }^{c}$ & 1 & $<-0.01$ & 1 & 162 \\
\hline BMI, diagnosis ${ }^{\mathrm{c}}$ & 1 & 0.02 & 0.5 & 146 \\
\hline Physical Activity & 1.5 & 0.4 & 0.4 & 164 \\
\hline Marital Status, current & 1.9 & 0.6 & 0.1 & 166 \\
\hline Marital Status, diagnosis & 0.5 & -0.8 & 0.1 & 166 \\
\hline
\end{tabular}

${ }^{\mathrm{a}}$ Coding and referent groups for dichotomous variables can be found in Appendix A

${ }^{b}$ Depression as measured by the CES-D Scale. Scores of $>16$ are indicative of depressive symptoms.

${ }^{c}$ Measured continuously

${ }^{\mathrm{d}}$ Referent Group

${ }^{\mathrm{e}}$ The Charlson Comorbidity risk groups are defined based on the scores received. A score no risk (0), low risk (1-2), moderate risk (3-4), and high risk (5-8)

It is important to note that the four hypotheses outlined in the statistical plan were determined prior to analysis of the data. Following data analysis, all subjects that were treated with radiation therapy were found to have invasive disease. (Table 4.3) Therefore, 
stage of disease and treatment were proxies for one another and hypothesis 1 and 2 did not measure separate associations.

When analyzing the relationship between treatment and sexual dysfunction, radiation therapy was significantly associated with sexual dysfunction $(O R=3.6,95 \% \mathrm{CI}$ [1.4-9.3]) and depression was also found to be significantly associated. Age, socioeconomic factors (ethnicity, education, and income), physical characteristics, and behavioral characteristics were added to the model, one by one, to determine if there were significant associations. Depression, stage of disease, and radiation were the only consistently significant variables. In addition to models that only included significant variables, models that included variables that were found to be nearly significant during univariate analysis, and models defined by socioeconomic class and Physical and Behavioral characteristics were also constructed. The final model used to analyze the relationship between treatment and sexual dysfunction included the variables treatment and depression. Table 4.9 represents examples of models used to investigate the treatment and sexual dysfunction relationship.

When investigating the relationship between stage of disease and sexual dysfunction, stage was significantly associated with sexual dysfunction $(O R=3.7,95 \% \mathrm{CI}$ [1.8-7.6]). The only significant covariate was depression. Age, socioeconomic factors, physical characteristics, and behavioral characteristics were not significantly associated with sexual dysfunction or were confounders of the relationship between sexual dysfunction and stage.

Models were built by adding covariates one by one until all variables listed in the statistical plan had been added. Again, when the model included all variables significant 
associations with covariates (with the exception of depression) were not found.

Alternative models were created based on socioeconomic status and physical and behavioral characteristics as well, but again only depression and stage of disease were significantly associated. Tables 4.10 represent examples of models used to investigate the relationship between sexual dysfunction, radiation, and stage.

In models where radiation therapy was investigated as a predictor for sexual dysfunction, adjustment for stage reduced the effect estimate and radiation was no longer significant $(O R=1.9,95 \%$ CI [0.7-5.3]). Although stage was a confounder for the association of radiation with sexual dysfunction, this was not the case when evaluating the effect of stage. In a model where stage was the independent variable, adjustment for radiation did not attenuate the association $(O R=2.9,95 \% \mathrm{CI}[1.5-7.1])$. This is because all women who had radiation treatment were diagnosed with invasive disease, but not all women with invasive disease received radiation therapy. Therefore, it was not possible to evaluate treatment therapy and only sexual dysfunction's association with stage of disease could be evaluated. Lastly, depression was found to be an independent predictor of sexual dysfunction. 
Table 4.9 Models Used to Describe the Effect of Radiation Therapy on Sexual Dysfunction

\begin{tabular}{|c|c|c|c|c|c|c|}
\hline Model & $n$ & Covariates & $\begin{array}{c}\text { Parameter } \\
\text { Estimates }\end{array}$ & $\begin{array}{c}p \\
\text { (Parameter } \\
\text { Estimates) }\end{array}$ & $\begin{array}{l}\text { Odds } \\
\text { Ratio }\end{array}$ & CI \\
\hline $\begin{array}{l}\text { Adjusting for Socioeconomic } \\
\text { Factors }\end{array}$ & 159 & $\begin{array}{l}\text { Age, } \text { current }^{\mathrm{a}} \\
\text { Depression }^{\mathrm{b}} \\
\text { Ethnicity } \\
\text { White, Non-Hispanic } \\
\text { Hispanic } \\
\text { Other } \\
\text { Education, current } \\
\text { High School Graduate or } \\
\text { Less } \\
\text { Some College } \\
\text { College Graduate } \\
\text { Graduate School }\end{array}$ & $\begin{array}{c}-0.01 \\
1.2 \\
- \\
-0.3 \\
0.6 \\
0.1 \\
0.4 \\
0.2 \\
-\end{array}$ & $\begin{array}{c}0.01 \\
<0.01 \\
- \\
0.5 \\
0.5 \\
0.9 \\
0.5 \\
0.8 \\
-\end{array}$ & 3.9 & $1.4-11.4$ \\
\hline $\begin{array}{l}\text { Adjusting for Physical or } \\
\text { Behavioral Characteristics }\end{array}$ & 157 & $\begin{array}{l}\text { Depression } \\
\text { DMI, current }^{\mathrm{a}} \\
\text { Bhysical Activity } \\
\text { Charlson Comorbidity Index }^{\mathrm{d}} \\
\text { No Risk }^{c} \\
\text { Low Risk } \\
\text { Moderate Risk } \\
\text { High Risk } \\
\text { Marital Status, current }\end{array}$ & $\begin{array}{c}1.3 \\
-0.04 \\
0.4 \\
\\
- \\
-0.7 \\
12.8 \\
0.3 \\
0.7\end{array}$ & $\begin{array}{c}<0.01 \\
0.2 \\
0.5 \\
\\
- \\
0.2 \\
1 \\
0.8 \\
0.1\end{array}$ & 3.4 & $1.1-9.8$ \\
\hline $\begin{array}{l}\text { Adjusting for Depression and } \\
\text { Stage }\end{array}$ & 163 & Depression $^{b}$ & 1.2 & $<0.01$ & 1.9 & $0.7-5.3$ \\
\hline
\end{tabular}




\begin{tabular}{|c|c|c|c|c|c|c|}
\hline & & Stage $^{e}$ & 1.1 & $<0.01$ & & \\
\hline $\begin{array}{l}\text { Final Model: Adjusting for } \\
\text { Depression }\end{array}$ & 165 & Depression $^{b}$ & 1.2 & $<0.01$ & 3.6 & $1.4-9.3$ \\
\hline
\end{tabular}

${ }^{a}$ Measured continuously

${ }^{b}$ Depression as measured by the CES-D Scale. Scores of $>16$ are indicative of depressive symptoms

'Referent Group

${ }^{\mathrm{d}}$ The Charlson Comorbidity risk groups are defined based on the scores received. The groups were categorized as follows high risk (5-8), moderate risk (3-4), low risk (1-2), and no risk (0).

${ }^{\mathrm{e}} \mathrm{Stage}$ is modeled as a dichotomous variable with in situ and invasive cancer categories. The in situ group is used as the referent group 
Table 4.10 Models Used to Describe the Effect of Stage of Cervical Cancer on Sexual Dysfunction

\begin{tabular}{|c|c|c|c|c|c|c|}
\hline Model & $n$ & Covariates & $\begin{array}{l}\text { Parameter } \\
\text { Estimates }\end{array}$ & $\begin{array}{c}p \\
\text { (Parameter } \\
\text { Estimates) }\end{array}$ & $\begin{array}{l}\text { Odds } \\
\text { Ratio }\end{array}$ & CI \\
\hline $\begin{array}{l}\text { Adjusting for Socioeconomic } \\
\text { Factors }\end{array}$ & 158 & $\begin{array}{l}\text { Age, } \text { current }^{\mathrm{a}} \\
\text { Depression }^{\mathrm{b}} \\
\text { Ethnicity } \\
\text { White, Non-Hispanic }{ }^{\mathrm{c}} \\
\text { Hispanic } \\
\text { Other } \\
\text { Education, current } \\
\text { High School Graduate or } \\
\text { Less } \\
\text { Some College } \\
\text { College Graduate } \\
\text { Graduate School }\end{array}$ & $\begin{array}{c}-0.01 \\
1.2 \\
- \\
-0.1 \\
0.6 \\
\\
-0.2 \\
0.1 \\
-0.1 \\
-\end{array}$ & $\begin{array}{c}0.7 \\
<0.01 \\
- \\
0.8 \\
0.4 \\
\\
0.7 \\
0.8 \\
0.9 \\
-\end{array}$ & 3.5 & $1.6-7.5$ \\
\hline $\begin{array}{l}\text { Adjusting for Physical or Behavioral } \\
\text { Characteristics }\end{array}$ & 156 & $\begin{array}{l}\text { Depression }^{\mathrm{b}} \\
\text { BMI, } \text { current }^{\mathrm{a}} \\
\text { Physical Activity } \\
\text { Charlson Comorbidity Index }^{\mathrm{d}} \\
\text { No Risk }^{\mathrm{c}} \\
\text { Low Risk } \\
\text { Moderate Risk } \\
\text { High Risk } \\
\text { Marital Status, current }\end{array}$ & $\begin{array}{c}1.3 \\
-0.03 \\
0.4 \\
\\
- \\
-0.8 \\
15.2 \\
-0.2 \\
0.7\end{array}$ & $\begin{array}{c}<0.01 \\
0.3 \\
0.4 \\
\\
- \\
0.1 \\
1 \\
0.9 \\
0.1\end{array}$ & 3.2 & $1.5-7.1$ \\
\hline $\begin{array}{l}\text { Adjusting for Depression and } \\
\text { Radiation }\end{array}$ & 163 & Depression $^{\mathrm{b}}$ & 1.2 & $<0.01$ & 2.9 & $1.3-6.5$ \\
\hline
\end{tabular}




\begin{tabular}{l|l|l|c|c|c|c} 
& Radiation $^{\mathrm{e}}$ & 0.6 & 0.2 & & \\
\hline $\begin{array}{l}\text { Final Model : Adjusting for } \\
\text { Depression }\end{array}$ & 164 & & & & 3.7 & $1.8-7.6$ \\
\hline
\end{tabular}

${ }^{\mathrm{a}}$ Measured continuously

bDepression as measured by the CES-D Scale. Modeled as a dichotomous variable with the "depressed" group having scores of $\geq 16$ and the "not depressed" group having scores of $<16$. The "not depressed" group was considered to be the referent group

\section{${ }^{\mathrm{c}}$ Referent Group}

${ }^{\mathrm{d}}$ The Charlson Comorbidity risk groups are defined based on the scores received. The groups were categorized as follows high risk (5-8), moderate risk (3-4), low risk (1-2), and no risk (0).

"Radiation is modeled as a dichotomous variable "radiation" and "no radiation" categories. The "no radiation" group is used as the referent group. 


\subsection{Depression and Stage}

Stage of disease was not found to be a significant predictor of depression. In univariate analyses several covariates were found to be significantly associated with depression. However, the only variable that remained significant throughout modelbuilding in multivariate analysis was self-reported QOL at the time of the interview. Model building was completed in a stepwise fashion to start and alternative models were created subsequently (i.e. models based on physical or behavior characteristics, socioeconomic class) In the final model, controlling only for self-reported QOL, stage was still not found to be a significant predictor of depression, (OR $0.995 \% \mathrm{CI}[0.5-1.8]$ ). Table 4.11 represents the univariate effects on depression. Table 4.12 represents examples of some of the models used to investigate the relationship between depression and stage.

Table 4.11 Univariate Models Describing the Effects on Depression ${ }^{a, b}$

\begin{tabular}{|c|c|c|c|c|}
\hline Variable Name & Odds Ratio & Beta & $p$ & $n$ \\
\hline Stage & 1.1 & 0.1 & 0.7 & 191 \\
\hline Sexual Dysfunction & 3.3 & 1.2 & $<0.01$ & 166 \\
\hline Age, current $t^{c}$ & 1 & $<0.01$ & 0.7 & 192 \\
\hline Age, diagnosis ${ }^{\mathrm{c}}$ & 1 & 0.02 & 0.4 & 193 \\
\hline Ethnicity & & & & 191 \\
\hline Other & 1.6 & 0.5 & 0.5 & \\
\hline Hispanic & 1.4 & 0.3 & 0.4 & \\
\hline White, Non-Hispanic $^{d}$ & - & - & - & \\
\hline Education, current & & & & 192 \\
\hline HS graduate or less & 2.8 & 1 & 0.1 & \\
\hline Some college & 2.4 & 0.9 & 0.1 & \\
\hline College graduate & 0.5 & -0.8 & 0.3 & \\
\hline
\end{tabular}




\begin{tabular}{|c|c|c|c|c|}
\hline Graduate school $^{\mathrm{d}}$ & - & - & - & \\
\hline Education, diagnosis & & & & 189 \\
\hline HS graduate or less & 2.8 & 1 & 0.05 & \\
\hline Some college & 2.2 & 0.8 & 0.1 & \\
\hline College graduate & 0.5 & -0.7 & 0.3 & \\
\hline Graduate school $^{\mathrm{d}}$ & - & - & - & \\
\hline Income, current & & & & 166 \\
\hline$<\$ 10,000-\$ 14,999$ & 4 & 1.4 & $<0.01$ & \\
\hline$\$ 15,000-\$ 29,999$ & 3.4 & 1.2 & $<0.01$ & \\
\hline$\$ 30,000-\$ 39,999$ & 2.7 & 1 & 0.04 & \\
\hline$>\$ 50,000^{\mathrm{d}}$ & 0 & 0 & 0 & \\
\hline Income, diagnosis & & & & 166 \\
\hline$<\$ 10,000-\$ 14,999$ & 2.5 & 0.9 & 0.1 & \\
\hline$\$ 15,000-\$ 29,999$ & 1.9 & 0.7 & 0.2 & \\
\hline$\$ 30,000-\$ 39,999$ & 1.5 & 0.4 & 0.4 & \\
\hline$>\$ 50,000^{\mathrm{d}}$ & - & - & - & \\
\hline Insurance Status & 2.5 & 0.9 & 0.03 & 188 \\
\hline Charlson Comorbidity Index ${ }^{\mathrm{e}}$ & & & & 189 \\
\hline High Risk & 10.4 & 2.3 & 0.04 & \\
\hline Moderate Risk & 2.6 & 1 & 0.4 & \\
\hline Low Risk & 1.8 & 0.6 & 0.1 & \\
\hline No Risk ${ }^{d}$ & - & - & - & \\
\hline $\mathrm{BMI}$, current $^{\mathrm{c}}$ & 1.1 & 0.1 & 0.04 & 189 \\
\hline BMI, diagnosis ${ }^{c}$ & 1.1 & 0.1 & 0.05 & 165 \\
\hline Physical Activity & 1.8 & 0.6 & 0.1 & 191 \\
\hline Marital Status, current & 1.7 & 0.5 & 0.1 & 193 \\
\hline Marital Status, diagnosis & 1.1 & 0.1 & 0.7 & 193 \\
\hline Smoking Habits & 1.2 & 0.2 & 0.5 & 193 \\
\hline Drinking Habits & 0.8 & -0.2 & 0.5 & 192 \\
\hline Menstrual Status, current & 1 & -0.01 & 1 & 188 \\
\hline
\end{tabular}




\begin{tabular}{|c|c|c|c|c|}
\hline Menstrual Status, diagnosis & 1.1 & 0.1 & 0.8 & 186 \\
\hline Self-Reported QOL, current & & & & 191 \\
\hline Excellent $^{d}$ & - & - & - & \\
\hline Very Good & 2 & 0.7 & 0.2 & \\
\hline Good & 5.3 & 1.7 & $<0.01$ & \\
\hline Poor/Fair & 16.3 & 2.8 & $<0.01$ & \\
\hline $\begin{array}{l}\text { Self-Reported QOL, } 2 \text { years post- } \\
\text { diagnosis } \\
\quad \text { Excellent }^{\mathrm{d}}\end{array}$ & - & - & - & 192 \\
\hline Very Good & 1.1 & 0.1 & 0.9 & \\
\hline Good & 2.7 & 1 & 0.02 & \\
\hline Poor/Fair & 4.9 & 1.6 & $<0.01$ & \\
\hline
\end{tabular}

\footnotetext{
${ }^{\mathrm{a}}$ Depression as measured by the CES-D Scale. Scores of $>16$ are indicative of depressive symptoms

${ }^{b}$ Coding and referent groups for dichotomous variables can be found in Appendix A

${ }^{c}$ Measured continuously

${ }^{\mathrm{d}}$ Referent Group

${ }^{\mathrm{e}}$ The Charlson Comorbidity risk groups are defined based on the scores received. The groups were categorized as follows high risk (5-8), moderate risk (3-4), low risk (1-2), and no risk (0).
} 
Table 4.12 Models Used to Describe the Effect of Stage of Cervical Cancer on Depression

\begin{tabular}{|c|c|c|c|c|c|c|}
\hline Model & $n$ & Covariates & $\begin{array}{l}\text { Parameter } \\
\text { Estimates }\end{array}$ & $\begin{array}{c}p \\
\text { (Parameter } \\
\text { Estimates) }\end{array}$ & $\begin{array}{l}\text { Odds } \\
\text { Ratio }\end{array}$ & CI \\
\hline Adjusting for Socioeconomic Factors & 156 & $\begin{array}{l}\text { Age, } \text { current }^{\mathrm{a}} \\
\text { Ethnicity } \\
\text { White, Non-Hispanic }{ }^{\mathrm{b}} \\
\text { Hispanic } \\
\text { Other } \\
\text { Education, current } \\
\text { High school graduate or less } \\
\text { Some college } \\
\text { College graduate } \\
\text { Graduate School } \\
\text { Insurance } \\
\text { Income, current } \\
\$ 10,000-\$ 14,999 \\
\$ 15,000-\$ 29,999 \\
\$ 30,000-\$ 39,999 \\
\$ 50,000+{ }^{b}\end{array}$ & $\begin{array}{c}-0.01 \\
- \\
0.01 \\
0.4 \\
\\
0.7 \\
0.6 \\
-0.7 \\
- \\
1.1 \\
\\
1 \\
0.9 \\
1.2 \\
-\end{array}$ & $\begin{array}{c}0.7 \\
- \\
1 \\
0.6 \\
\\
0.3 \\
0.3 \\
0.3 \\
- \\
0.03 \\
0.1 \\
0.1 \\
0.03 \\
-\end{array}$ & 1.3 & $0.6-2.8$ \\
\hline $\begin{array}{l}\text { Adjusting for Physical and Behavioral } \\
\text { Characteristics }\end{array}$ & 180 & $\begin{array}{l}\text { BMI, } \text { current }^{\mathrm{a}} \\
\text { Physical activity, past month } \\
\text { Charlson Comorbidity Index } \\
\text { No Risk }^{\mathrm{b}} \\
\text { Low Risk } \\
\text { Moderate Risk } \\
\text { High Risk }\end{array}$ & $\begin{array}{c}0.04 \\
0.4 \\
- \\
0.3 \\
0.6 \\
2.8\end{array}$ & $\begin{array}{c}0.1 \\
0.4 \\
- \\
0.4 \\
0.7 \\
0.02\end{array}$ & 0.8 & $0.4-1.7$ \\
\hline
\end{tabular}




\begin{tabular}{|c|c|c|c|c|c|c|}
\hline & & $\begin{array}{l}\text { Self-reported QOL, current } \\
\text { Excellent } \\
\text { Very Good } \\
\text { Good } \\
\text { Fair/Poor }\end{array}$ & $\begin{array}{c}- \\
0.8 \\
1.6 \\
2.6\end{array}$ & $\begin{array}{c}- \\
0.1 \\
<0.01 \\
<0.01\end{array}$ & & \\
\hline $\begin{array}{l}\text { Final Model: Adjusting for self-reported } \\
\text { QOL } \\
\text { (1 collapsed category) }\end{array}$ & 189 & $\begin{array}{l}\text { Excellent/Very good } \\
\text { Good } \\
\text { Fair/Poor }\end{array}$ & $\begin{array}{l}- \\
1.3 \\
2.4\end{array}$ & $\begin{array}{c}- \\
<0.01 \\
<.0 .01\end{array}$ & 0.9 & $0.5-1.8$ \\
\hline
\end{tabular}

${ }^{\mathrm{a}}$ Measured continuously

${ }^{\mathrm{b}}$ Referent Group

${ }^{\mathrm{c}}$ The Charlson Comorbidity Index risk groups are defined based on the scores received. The groups were categorized as follows high risk (5-8), moderate risk $(3-4)$, low risk (1-2), and no risk (0). 


\subsection{MOS 36-item Short Form Survey (SF-36) Physical and Mental Health Summary}

\section{Scores}

\subsubsection{Physical Health Summary Score, Depression, and Sexual Dysfunction}

During univariate analysis, several variables were significantly associated with a difference in the mean SF-36 physical health summary score, including the variables for depression and sexual dysfunction. During model building all significant variables found during univariate analysis were added one by one to a multivariate model. Alternatively, models based on socioeconomic factors and physical and behavioral characteristics were also created. The final model created accounted for approximately $43 \%$ of the variance, and included the following variables: depression, sexual dysfunction, BMI at the time of interview, the Charlson Comorbidity Index, and alcohol use.

According to the results, depression results in a 16 point decrease $(p<0.01)$ in the physical health score. Sexual dysfunction accounts for a 6-point decrease $(p=0.03)$ in the physical health score, BMI decreases the score by $0.5(p=0.01)$, and alcohol use increases the score by 6 points $(p=0.02)$. Lastly, being classified as "high or moderate risk" on the Charlson Comorbidity Index decreases the physical health score by 23 points $(p<0.01)$, and being classified as "low risk" decreases the score by 7 points $(p=0.02)$. Table 4.13 details the effects on the SF-36 Physical Health Summary Score during univariate analysis. Table 4.14 details examples of models that included variables based on socioeconomic factors or physical and behavioral characteristics. 
Table 4.13 Univariate Models Describing the Effect on the SF-36 Physical Health Summary Score ${ }^{a}$

\begin{tabular}{|c|c|c|c|c|}
\hline Variable & $\mathbf{R}^{2}$ & Beta & $p$ & $n$ \\
\hline CES_D ${ }^{b}$ & 0.2 & -21.3 & $<0.01$ & 162 \\
\hline Sexual Dysfunction & 0.1 & -12.3 & $<0.01$ & 189 \\
\hline Age, current $^{c}$ & 0.1 & -0 & $<0.01$ & 189 \\
\hline Age, diagnosis ${ }^{\mathrm{c}}$ & 0.03 & -0.5 & 0.01 & 189 \\
\hline Ethnicity & 0.01 & & & 188 \\
\hline Other & & -9.1 & 0.2 & \\
\hline Hispanic & & -0.7 & 0.9 & \\
\hline White, Non-Hispanic ${ }^{d}$ & & - & - & \\
\hline Education, current & 0.1 & & & 185 \\
\hline HS graduate or less & & -16.2 & $<0.01$ & \\
\hline Some college & & -10.7 & 0.02 & \\
\hline College graduate & & -3.8 & 0.5 & \\
\hline Graduate school $^{\mathrm{d}}$ & & - & - & \\
\hline Education, diagnosis & 0.1 & & & 189 \\
\hline $8^{\text {th }}$ grade or less & & -31.6 & $<0.01$ & \\
\hline Some HS/ HS graduate & & -15.2 & $<0.01$ & \\
\hline Some college & & -6.2 & 0.1 & \\
\hline College Grad/Graduate school ${ }^{\mathrm{d}}$ & & - & - & \\
\hline Income, current & 0.2 & & & 164 \\
\hline$<\$ 10,000$ & & -25.3 & $<0.01$ & \\
\hline$\$ 10,000-\$ 19,999$ & & -13.5 & 0.01 & \\
\hline$>\$ 20,000^{\mathrm{d}}$ & & - & - & \\
\hline Income, diagnosis & 0.2 & & & 164 \\
\hline$<\$ 10,000$ & & -24.6 & $<0.01$ & \\
\hline$\$ 10,000-\$ 14,999$ & & -9.2 & 0.1 & \\
\hline$\$ 15,000-\$ 19,999$ & & -16.9 & $<0.01$ & \\
\hline$\$ 20,000-\$ 29,999$ & & 0.9 & 0.9 & \\
\hline$\$ 30,000-\$ 39,999$ & & -2.5 & 0.6 & \\
\hline
\end{tabular}




\begin{tabular}{|c|c|c|c|c|}
\hline$>\$ 50,000^{d}$ & & & & \\
\hline Insurance Status & $<0.01$ & -1.1 & 0.8 & 185 \\
\hline Charlson Comorbidity Index ${ }^{\mathrm{e}}$ & 0.2 & & & 184 \\
\hline High Risk & & -36.6 & $<0.01$ & \\
\hline Moderate Risk & & -37.6 & $<0.01$ & \\
\hline Low Risk & & -16.4 & $<0.01$ & \\
\hline No Risk ${ }^{d}$ & & - & - & \\
\hline BMI, current ${ }^{c}$ & 0.1 & -0.8 & $<0.01$ & 184 \\
\hline BMI, diagnosis $^{c}$ & 0.2 & -1.4 & $<0.01$ & 162 \\
\hline Smoking Habits & 0.03 & -7.2 & 0.03 & 190 \\
\hline Drinking Habits & 0.1 & 10.8 & $<0.01$ & 189 \\
\hline Physical Activity & 0.1 & -15.3 & $<0.01$ & 188 \\
\hline
\end{tabular}

${ }^{\mathrm{a} C o d i n g}$ and referent groups for dichotomous variables can be found in Appendix A

${ }^{b}$ Depression as measured by the CES-D Scale. Scores of $>16$ are indicative of depressive symptoms cMeasured continuously

${ }^{\mathrm{d}}$ Referent Group

${ }^{\mathrm{e}}$ The Charlson Comorbidity risk groups are defined based on the scores received. The groups were categorized as follows high risk (5-8), moderate risk (3-4), low risk (1-2), and no risk (0). 
Table 4.14 Models Describing the Effect on Cervical Cancer Survivor's SF-36 Physical Health Score

\begin{tabular}{|c|c|c|c|c|c|}
\hline Model & $n$ & Covariates & $\begin{array}{l}\text { Parameter } \\
\text { Estimates }\end{array}$ & $\begin{array}{c}\boldsymbol{p} \\
\text { (Parameter } \\
\text { Estimates) } \\
\end{array}$ & $\mathbf{R}^{2}$ \\
\hline Socioeconomic Factors, Depression and Sexual Dysfunction ${ }^{\mathrm{a}}$ & 139 & 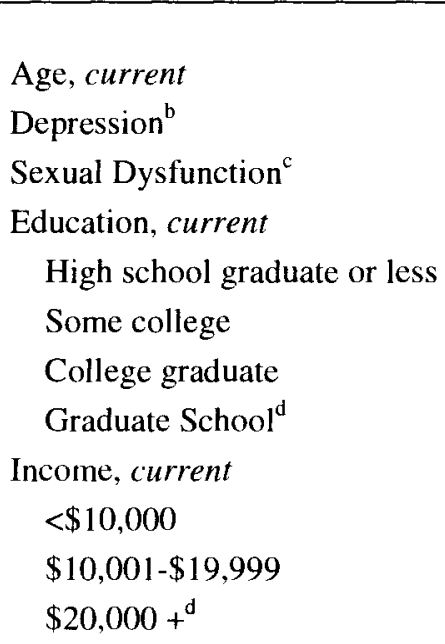 & $\begin{array}{l}-0.4 \\
-15.9 \\
-5.6 \\
-3.3 \\
-5.9 \\
-2.2 \\
- \\
-12.9 \\
-6.7 \\
-\end{array}$ & $\begin{array}{c}0.04 \\
<0.01 \\
0.01 \\
0.5 \\
0.2 \\
0.7 \\
- \\
\\
0.02 \\
0.2 \\
-\end{array}$ & 0.3 \\
\hline $\begin{array}{l}\text { Physical and Behavioral Characteristics, Depression and } \\
\text { Sexual Dysfunction }^{\text {a }}\end{array}$ & 154 & $\begin{array}{l}\text { Age, current } \\
\text { Depression }^{\mathrm{b}} \\
\text { Sexual Dysfunction }^{\mathrm{c}} \\
{\text { BMI, } \text { current }^{\mathrm{e}}}^{\text {Charlson Comorbidity Index }}{ }^{\mathrm{f}} \\
\text { High/Moderate Risk } \\
\text { Low Risk }^{\text {No Risk }}{ }^{\mathrm{d}} \\
\text { Alcohol Use } \\
\text { Physical Activity, past month }\end{array}$ & $\begin{array}{c}-0.3 \\
-16 \\
-5.7 \\
-0.5 \\
\\
-22 \\
-5.2 \\
- \\
5.6 \\
-3.7\end{array}$ & $\begin{array}{c}0.1 \\
<0.01 \\
0.05 \\
0.01 \\
\\
<0.01 \\
0.1 \\
- \\
0.03 \\
0.3\end{array}$ & 0.4 \\
\hline Final Model & 156 & & & & 0.4 \\
\hline
\end{tabular}




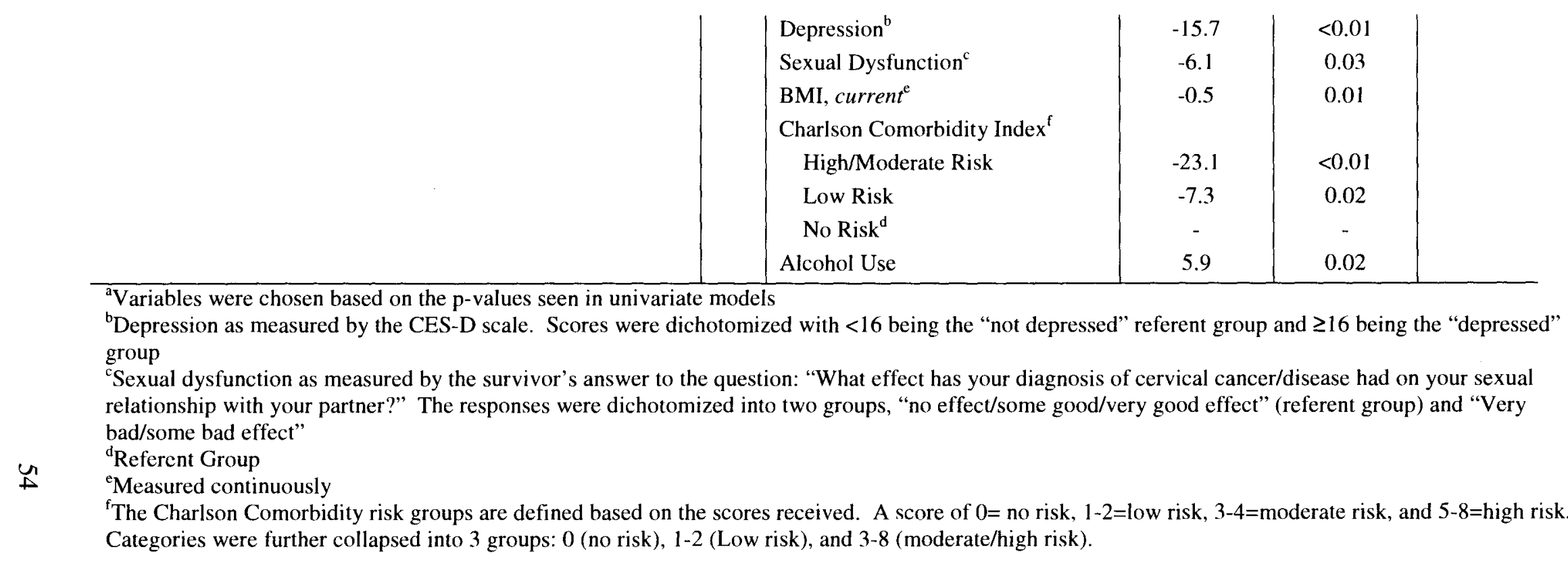




\subsubsection{Mental Health Summary Score, Depression, and Sexual Dysfunction}

The SF-36 Mental Health Summary Score was significantly associated with several covariates during univariate analysis, including depression and sexual dysfunction. During model building all significant variables found during univariate analysis were added one by one to the multivariate model. However, when all significant variables were modeled together, depression and sexual dysfunction were the only variables that were significant $(p<0.05$ level). Additionally, models based on socioeconomic factors and behavioral and physical characteristics were constructed. The final model included only depression and sexual dysfunction (both significant at the $(p<0.05)$ level $)$

Depression and sexual dysfunction accounted for $45 \%$ of the variance. Depression decreases the mental health score by 28 points $(p<0.01)$ and sexual dysfunction decreases the score by 7 points $(p=0.01)$. Table 4.15 details the effects on the mental health summary score using univariate models and Table 4.16 represents examples of the multivariate models used. 
Table 4.15 Univariate Models Describing the Effect on the SF-36 Mental Health Summary Score ${ }^{a}$

\begin{tabular}{|c|c|c|c|c|}
\hline Variable Name & $\mathbf{R}^{2}$ & Beta & $p$ & $n$ \\
\hline$\overline{C E S \_D}{ }^{b}$ & 0.4 & -29.6 & $<0.01$ & 162 \\
\hline Sexual Dysfunction & 0.1 & -14.1 & $<0.01$ & 162 \\
\hline Age, current ${ }^{\mathrm{c}}$ & $<0.01$ & -0.1 & 0.4 & 189 \\
\hline Age, diagnosis ${ }^{\mathrm{c}}$ & 0.01 & -0.3 & 0.1 & 189 \\
\hline Ethnicity & $<0.01$ & & & 188 \\
\hline Other & & -7.8 & 0.3 & \\
\hline Hispanic & & -3.4 & 0.4 & \\
\hline White, Non-Hispanic $^{d}$ & & - & - & \\
\hline Education, current & 0.03 & & & 185 \\
\hline HS graduate or less & & -9 & 0.1 & \\
\hline Some college & & -6.1 & 0.2 & \\
\hline College graduate & & -1.2 & 0.8 & \\
\hline Graduate school $^{\mathrm{d}}$ & & - & - & \\
\hline Education, diagnosis & 0.04 & & & 189 \\
\hline $8^{\text {th }}$ grade or less & & -13.6 & 0.2 & \\
\hline Some HS or HS graduate & & -9.9 & 0.01 & \\
\hline Some college & & -5.9 & 0.1 & \\
\hline College Grad/Graduate school ${ }^{d}$ & & - & - & \\
\hline Income, current & 0.1 & & & 164 \\
\hline$<\$ 10,000$ & & -20.1 & $<0.01$ & \\
\hline$\$ 10,000-\$ 19,999$ & & -11.8 & 0.02 & \\
\hline$>\$ 20,000^{d}$ & & - & - & \\
\hline Income, diagnosis & 0.1 & & & 164 \\
\hline$<\$ 10,000-\$ 14,999$ & & -16 & $<0.01$ & \\
\hline$\$ 15,000-\$ 19,999$ & & -21.5 & $<0.01$ & \\
\hline$\$ 20,000-\$ 39,999$ & & -4.5 & 0.3 & \\
\hline$>\$ 50,00^{\mathrm{d}}$ & & - & - & \\
\hline Insurance Status & $<0.01$ & -3.7 & 0.4 & 185 \\
\hline
\end{tabular}




\begin{tabular}{|c|c|c|c|c|}
\hline Charlson Comorbidity Index ${ }^{c}$ & 0.17 & & & 184 \\
\hline High Risk & & -50.6 & $<0.01$ & \\
\hline Moderate Risk & & -16.6 & 0.1 & \\
\hline Low Risk & & -11.7 & $<0.01$ & \\
\hline No Risk ${ }^{d}$ & & - & - & \\
\hline BMI, current ${ }^{c}$ & 0.01 & -0.3 & 0.2 & 184 \\
\hline BMI, diagnosis ${ }^{c}$ & 0.1 & -0.8 & $<0.01$ & 162 \\
\hline Smoking Habits & 0.1 & -3.4 & 0.3 & 190 \\
\hline Drinking Habits & 0.01 & 4.49 & 0.2 & 189 \\
\hline Physical Activity & 0.1 & 13.2 & $<0.01$ & 188 \\
\hline
\end{tabular}

${ }^{a}$ Coding and referent groups for dichotomous variables can be found in Appendix A

${ }^{b}$ Depression as measured by the CES-D Scale. Scores of $>16$ are indicative of depressive symptoms ${ }^{\mathrm{c}}$ Measured continuously

${ }^{\mathrm{d}}$ Referent Group

'The Charlson Comorbidity risk groups are defined based on the scores received. The groups were categorized as follows high risk (5-8), moderate risk (3-4), low risk (1-2), and no risk (0). 
Table 4.16 Models Describing the Effects on Cervical Cancer Survivor's SF-36 Mental Health Summary Score

$\begin{array}{llccc}\text { Model } & n & \text { Covariates } & \begin{array}{c}\text { Parameter } \\ \text { Estimates }\end{array} & p \\ & & \text { (Parameter } & \mathbf{R}^{2}\end{array}$

\begin{tabular}{|c|c|c|c|c|c|}
\hline & & & Estimates & $\begin{array}{l}\text { (Parameter } \\
\text { Estimates) }\end{array}$ & \\
\hline $\begin{array}{l}\text { All variables with significant estimates during } \\
\text { univariate analysis }\end{array}$ & 135 & 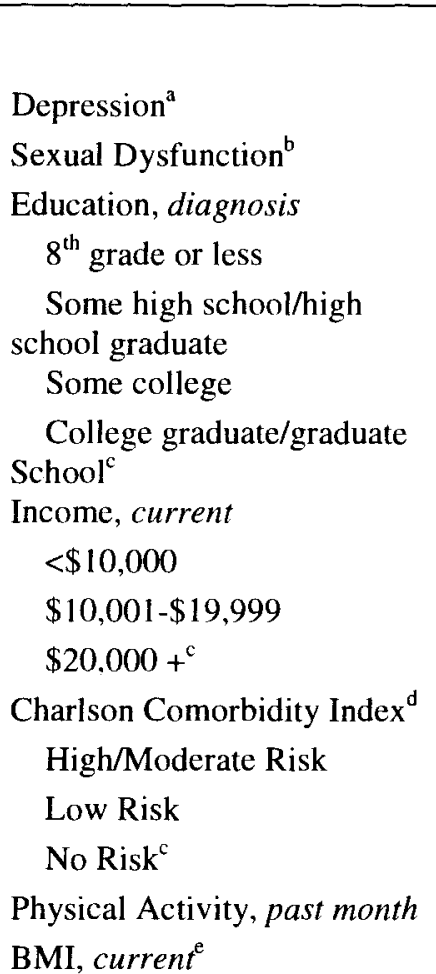 & $\begin{array}{c}-26.8 \\
-4.9 \\
12.9 \\
0.5 \\
0.4 \\
- \\
\\
-2.3 \\
-5.7 \\
- \\
-18.4 \\
-2.3 \\
- \\
-4.1 \\
0.01\end{array}$ & $\begin{array}{c}<0.01 \\
0.01 \\
0.5 \\
0.9 \\
0.9 \\
- \\
\\
0.7 \\
0.2 \\
- \\
0.01 \\
0.5 \\
- \\
0.2 \\
1\end{array}$ & 0.5 \\
\hline $\begin{array}{l}\text { Depression, sexual dysfunction, and the } \\
\text { Charlson Comorbidity Index }\end{array}$ & 160 & $\begin{array}{l}\text { Depression }^{\mathrm{a}} \\
\text { Sexual Dysfunction }^{\mathrm{b}} \\
\text { Charlson Comorbidity Index }^{\mathrm{d}} \\
\text { High/Moderate Risk } \\
\text { Low Risk }\end{array}$ & $\begin{array}{l}-25.6 \\
-6.3 \\
-19.9 \\
-3.5\end{array}$ & $\begin{array}{c}<0.01 \\
0.02 \\
<0.01 \\
0.2\end{array}$ & 0.5 \\
\hline
\end{tabular}




\begin{tabular}{|c|c|c|c|c|c|}
\hline & & No Risk ${ }^{c}$ & - & - & \\
\hline Final Model & 162 & $\begin{array}{l}\text { Depression }^{\mathrm{a}} \\
\text { Sexual Dysfunction }^{\mathrm{b}}\end{array}$ & $\begin{array}{l}-27.8 \\
-6.9\end{array}$ & $\begin{array}{c}<0.01 \\
0.01\end{array}$ & 0.5 \\
\hline
\end{tabular}

aDepression as measured by the CES-D scale. Scores were dichotomized with $<16$ being the "not depressed" referent group and $\geq 16$ being the "depressed" group ${ }^{b}$ Sexual dysfunction as measured by the survivor's answer to the question: "What effect has your diagnosis of cervical cancer/disease had on your sexual relationship with your partner?" The responses were dichotomized into two groups, "no effect/some good/very good effect" (referent group) and "Very $\mathrm{bad} / \mathrm{some}$ bad effect"

${ }^{c}$ Referent Group

${ }^{\mathrm{d}}$ The Charlson Comorbidity risk groups are defined based on the scores received. The groups were categorized as follows high risk (5-8), moderate risk (3-4), low risk (1-2), and no risk (0). Categories were further collapsed into 3 groups: 0 (no risk), 1-2 (Low risk), and 3-8 (moderate/high risk).

${ }^{\mathrm{e}}$ Measured continuously 


\section{CHAPTER 5}

\section{DISCUSSION}

The analysis conducted in this study found that stage of disease was a predictor of sexual dysfunction, radiation was a predictor of sexual dysfunction, depression was a predictor of sexual dysfunction independent of stage and treatment, and that depression and sexual dysfunction cause a decrease in the quality of Life (QOL) of survivors (as measured by the SF36 Physical and Mental Health Summary Scores). These findings parallel the findings in the literature surrounding cervical cancer quality of life. Most researchers have found that cervical cancer negatively affects the women's sexual relationships, mental health, and/or their overall quality of life.

\subsection{Associations with Sexual Dysfunction}

The SAQ was used to determine what aspects of life, which are common to cervical cancer survivors, might be associated with a higher risk of sexual dysfunction. In the literature, when the SAQ was utilized to measure sexual dysfunction, cancer survivors were found to have more problems surrounding sexual health than in comparison groups. (Gotay et al., 2008; Greimel et al., 2009) Although the data analyzed in this thesis found a slightly smaller frequency than Greenwald and McCorkle (2008) found, at least $25 \%$ of the women cited cervical cancer as causing problems in their sexual relationships.

\subsubsection{The a priori Hypotheses}


Two a priori hypotheses investigated the association between stage and sexual dysfunction and treatment and sexual dysfunction. However, when data analysis was completed the two hypotheses were found to be proxies of each other. The study sample was composed of a radiation therapy group that did not include both invasive and in situ cases. Only invasive cases composed the radiation group. Therefore, it was not possible to separate the effects of treatment from stage of disease on sexual dysfunction.

The majority of the literature focuses on treatment with regard to sexual dysfunction and not stage of disease. This is logical because as the stage of disease increases, so too does the probability of radiation therapy. And, even though strong associations exist between stage, sexual dysfunction, and treatment the true source of the dysfunction has not been identified. However, radiation therapy is often reported to be associated with negative effects on sexual function.

Frumovitz et al. (2005) found that patients who received radiation therapy as a form of treatment were diagnosed with a more advanced stage of disease. Additionally, studies that use treatment as the independent variable, especially treatment with radiation therapy, have found strong associations with poor sexual health. Radiation has been associated with significantly worse sexual dysfunction when compared to surgical forms of treatment, and has been associated with an increased number of anatomical changes that lead to dysfunction, (Frumovitz et al., 2005; Donovan et al., 2007; Bodurka et al., 2006)

\subsubsection{Focusing on the Relationship Between Sexual Function, Stage of Disease, and}

\section{Depression}


Associations between stage and sexual dysfunction and the differences from associations between stage and treatment need to be further studied in relation to sexual health. There are studies that have shown both variables are associated with dysfunction however, the relationship has not be separated in the literature. Therefore, the conclusiveness of the strong association with stage is hard to determine.

In the literature, if information is gathered on stage, most focus is placed on participant's time since diagnosis and associations related to stage are not considered. However, similar to the results of this thesis, Tzung-Yi et al. (2011) and Greenwald and McCorkle (2008) reported a significant association between stage of disease and sexual dysfunction.

In the study by Tzung-Yi et al., a cohort of Taiwanese women was investigated and the risk of sexual dysfunction with an increased stage was significantly increased (OR) $(4.34,95 \%$ CI [1.65-19.09]). Separately, Greenwald et al, found that when comparing invasive and noninvasive survivors, the noninvasive groups was less likely to report a negative impact on their sexual relationship.

The finding of depression in association with sexual dysfunction is also consistent with the literature. Specific issues surrounding infertility, deterioration of relationships, body image, and self-esteem have all been shown to be associated with sexual dysfunction in cervical cancer survivors. (Bermark et al., 1999; Baser, Li, and Carter, 2012) These issues could all result in depressive symptoms that could ultimately lead to problems with sexual functioning.

However, further research into the effect of depression on sexual health is required to separate the direction of causality. It is plausible that depression is causing 
sexual dysfunction as well as sexual dysfunction is causing depression. Knowing which condition is causative to the other would help to adequately treat the problems in cervical cancer quality of life.

\subsection{Quality of Life and the MOS 36-item Short Form Survey (SF-36)}

The finding that women in this study were found to have generally higher scores on the SF-36 scale, indicating a higher level of quality of life, is consistent with the literature. For the total population, the mean scores for both the physical and mental health summary scores are 50 (SD 10) (Wenzel et al., 2005) The mean scores reported by women in this study were higher. A review from Goncalves (2010) found that the same is true for most gynecological cancer studies.

The associations found in this study between quality of life and depression and sexual dysfunction are also supported in the literature. For example, Wenzel et al. (2005) found that better sexual functioning was positively associated with higher mental health summary scores. Also, Bartoces et al. (2009) found an association with self-esteem and the mental health summary score.

Contradictions in the literature occur when the association between quality of life and other covariates is investigated. Bartoces et al. (2009) studied the difference in physical and mental health summary scores by stage and reported that there was not a difference between invasive and noninvasive groups. Alternatively, Frumovitz et al. (2005) found that participants who were treated with radiation had a significantly lower physical health summary score. Lastly, Gotay et al. (2008) found that when cervical cancer survivors were compared to a normative sample of women, survivors had higher mental health scores (SF-36 subscale). 


\subsection{Strengths and Limitations}

\subsubsection{Limitations}

A clear limitation of this study is the cross sectional design which makes it impossible to determine the causal direction of the association between sexual dysfunction and depression. Does depression lead to an increased risk of sexual dysfunction, or is the dysfunction actually causing the depression? Also, in many cases the woman's sexual dysfunction could be a byproduct of her treatment for depression. (Basson, 2005) Therefore, while significant results were found, and support an association between sexual dysfunction and depression; further research is still needed to determine the true cause of both.

The sample collected is also a limitation of this study. First, low response rate may be a source of selection bias in this study. Given that so few women agreed to participate, it is plausible that the women that compose the sample are not representative of cervical cancer survivors. While the data collection process was designed to collect a random sample, the women who agreed to participate were in the minority. Also, the lack of in situ cases in the radiation treatment group, limits the ability of the study to make conclusions based on treatment and stage. Lastly, limited statistical power because of the small sample size is a limitation. Although, the associations found in this study were relatively strong.

\subsubsection{Strengths}

However, the study does add to the sparse literature that exists with regard to quality of life for cervical cancer survivors. In a 2006 review article by Vistad et al., only 23 studies relating to cervical cancer quality of life (including sexual dysfunction) were 
published between 1966 and 2005. This included longitudinal studies, cohorts, and retrospective studies and only eight studies were considered to use acceptable methodology. (Vistad et al., 2006)

\subsection{Future Implications}

The analyses conducted in this thesis prove a need for more focus to be placed on separating the effects that treatment and stage of disease have on sexual dysfunction. The strong association found between sexual dysfunction and stage of disease proves that the individual relationship should not be ignored. While treatment for cervical cancer becomes more aggressive with increasing cervical cancer stages, it has yet to be determined that stage itself does not have an independent effect. It is plausible that the effects of being diagnosed with advanced cervical disease cause sexual dysfunction, independently of treatment. However, because most of the research conducted focuses on the consequences of treatment, it is difficult to determine if stage has an effect or if the associations are a byproduct of treatment. Therefore, to adequately understand what causes sexual dysfunction more research should be conducted on comparing stage of disease with regard to sexual dysfunction.

While the research and awareness of the issue of quality of life in cervical cancer survivors has increased and become a focus for researchers, there is still not much information available. (Goncalves, 2010) Significant associations exist between invasive cervical cancer survivors, treatment options, depression and sexual dysfunction, and also sexual dysfunction, depression, and quality of life scores. However, the relationships should be further explored. There are many aspects to these relationships that have been 
left unexplained and therefore require more research to adequately help cervical cancer survivors in the future. 


\section{REFERENCES}

Abitbol, M. M. \& Davenport, J. H. (1974) Sexual dysfunction after therapy for cervical carcinoma. American Journal of Obstetrics Gynecology, 119(2), 181-189.

Advisory Committee on Immunization Practices (2011). Vaccines to Prevent Human Papillomavirus (Resolution No. 010/11-1 C.F.R.). Atlanta, GA: Centers for Diseases Control and Prevention. Retrieved from http://www.cdc.gov/vaccines/programs/vfc/downloads/resolutions/1011-1hpv.pdf

American Society of Clinical Oncology. (2012). Cervical Cancer. Retrieved from http://www.cancer.net/patient/Cancer+Types/Cervical+Cancer/ci.Cervical+Cance r.printer

Bartoces, M. G., Severson, R. K., Rusin, B. A., Schwartz, K. L., Ruterbusch, J. J., \& Neale, A. V. (2009). Quality of life and self-esteem of long-term survivors of invasive and noninvasive cervical cancer. Journal of Women's Health, 18(5), 655 661. doi: 10.1089/jwh.2008.0959

Baser, R. E., Li, Y., \& Carter, J. (2012). Psychometric validation of the female sexual function index (fsfi) in cancer survivors. Cancer. doi: 10.1002/cncr.26739

Basson, R. (2005). Women's sexual dysfunction: revised and expanded definitions. Canadian Medical Association Journal, 172 (10) , 1327-1333. doi: 10.1503/cmaj.1020174

Baumgartner, K. B., Fetherolf, J., Wheeler, C., Hunt, W. C., \& Key, C. (2003). Adaptation and Quality of Life Among Long-Term Cervical Cancer Survivors Final Report (Contract NIH/NCI, N01-PC-67007, Addendum 47. Submitted to Surveillance, Epidemiology, and End Results Program (SEER), National Cancer Institute. Albuquerque, NM: University of New Mexico School of Medicine.

Bergmark, K., Avall-Lundqvist, E., Dickman, P.W., Henningsohn, L., \& Steineck, G. (1999). Vaginal changes and sexuality in women with a history of cervical cancer. New England Journal of Medicine, 340(18), 1383-1389. 
Bodurka, D. C., \& Sun, C. C. (2006). Sexual function after gynecologic cancer. Obstetrics and Gynecology Clinics of North America, 33(4), 621-630, ix. doi: 10.1016/j.ogc.2006.09.006

Charlson, M. E., Pompei, P., Ales, K. L., \& MacKenzie, C. R. (1987). A new method of classifying prognostic comorbidity in logitudinal studies: Development and validation. Journal of Chronic Disease, 40(5), 373-383.

Centers for Disease Control and Prevention (2012). Human Papillomavirus (HPV). Retreived from http://www.cdc.gov/hpv/cancer.html

Centers for Disease Control and Prevention (2013). Genital HPV infection- Fact Sheet. Retrieved from http://www.cdc.gov/std/HPV/STDFact-HPV.htm\#a5

Cohen, J. (1988). Statistical Power for the Behavioral Sciences. Hillsdale, NJ: Lawrence Erlbaum, INC.

Donovan, K. A., Taliaferro, L. A., Alvarez, E. M., Jacobsen, P. B., Roetzheim, R. G., \& Wenham, R. M. (2007). Sexual health in women treated for cervical cancer: Characteristics and correlates. Gynecolic Oncology, 104(2), 428434. doi: 10.1016/j.ygyno.2006.08.009

Eifel, P., Berek, J. S., \& Thigpen, J. T. (2001) Cancer of the Cervix, Vagina, and Vulva. In DeVita, V., Hellman, K., Rosenberg, J.C. (Eds.), Cancer Principles and Practice of Oncology (6th ed.) (pp. 1526-1550). Lippincott Williams and Wilkins.

Ferrell, B. R., Dow, K. H., \& Grant, M. (1995). Measurement of the quality of life in cancer survivors. Quality of life research: an International journal of quality of life aspects of treatment, care, and rehabilitation, 4(6), 523-531.

Frumovitz, M., Sun, C. C., Schover, L. R., Munsell, M. F., Jhingran, A., Wharton, J. T., . .. Bodurka, D. C. (2005). Quality of life and sexual functioning in cervical cancer survivors. Journal of Clinical Oncologyl, 23(30), 7428-7436. doi:

$10.1200 /$ jco.2004.00.3996

Goncalves, V. (2010). Long-term quality of life in gynecological cancer survivors. Current Opinion in Obstetrics and Gynecology, 22, 30-35.

Gotay, C. C., Farley, J. H., Kawamoto, C. T., \& Mearig, A. (2008). Adaptation and quality of life among long-term cervical cancer survivors in the military health care system. Military Medicine, 173(10), 1035-1041.

Greenwald, H. P., \& McCorkle, R. (2008). Sexuality and sexual function in long-term survivors of cervical cancer. Journal of Women's Health, 17(6), 955-963. doi: 10.1089/jwh.2007.0613 
Greimel, E. R., Winter, R., Kapp, K. S., \& Haas, J. (2009). Quality of life and sexual functioning after cervical cancer treatment: a Long-term follow-up study. PsychoOncology, 18(5), 476-482. doi: 10.1002/pon.1426

Howlander, N., Noone, A., Krapcho, M., Neyman, N., Aminou, R., Altekruse, S., . . . Cronin, K. (2012). SEER Cancer Statistics Review, 1975-2009 (Vinatage 2009 Populations), National Cancer Institute. Bethesda, MD. Retrieved from http://seer.cancer.gov/csr/1975_2009_pops09/

Jensen, P. T., Groenvold, M., Klee, M. C., Thranov, I., Petersen, M. A., \& Machin, D. (2004). Early-stage cervical carcinoma, radical hysterectomy, and sexual function. A longitudinal study. Cancer, 100(1), 97-106. doi: 10.1002/cncr.11877

Juraskova, I., Butow, P., Bonner, C., Robertson, R., Sharpe, L. (2011). Sexual adjustment following early stage cervical and endometrial cancer: prospective controlled multi-centre study. Psycho-Oncology. Doi: 10.1002/pon.2066

Lindau, S. T., Gavrilova, N., \& Anderson, D. (2007). Sexual morbidity in very long term survivors of vaginal and cervical cancer: A comparison to national norms. Gynecologic Oncology, 106(2), 413-418. doi:10.1016/j.ygyno.2007.05.017

Markowitz, L. E., Dunne, E. F., Saraiya, M., Lawson, H. W., Chesson, H., \& Unger, E. (2007). Quadrivalent Human Papillomavirus Vaccine. MMWR 56(RRO2), 1-24.

McGregor, J. C., Kim, P. W., Perencevich, E. N., Bradham, D. D., Furuno, J. P., Kaye, K. S., . . Harris, A. D. (2005). Utility of the chronic disease score and Charlson Comorbidity Index as comorbidity measures for use in epidemiologic studies of antibiotic-resistant organisms. American Journal of Epidemiology, 161(5), 483493. doi: $10.1093 / \mathrm{aje} / \mathrm{kwi068}$

McHorney, C. A., Ware, J. E., Lu, J. F. R., \& Sherbourne, C.D. (1994). The MOS 36Item Short-Form Health Survey (SF-36®): III. tests of data quality, scaling assumptions and reliability across diverse patient groups. Medical Care, 32(4), $40-66$.

National Cancer Institute (2012). HPV and Cancer. Retrieved from http://www.cancer.gov/cancertopics/factsheet/Risk/HPV

Park, S. Y., Bae, D. S., Nam, J. H., Park, C. T., Cho, C. H., Lee, J. M., . . Yun, Y. H. (2007). Quality of life and sexual problems in disease-free survivors of cervical compared with the general population. Cancer, 110(12), 2716-25.

Pieterse, Q. D., Maas, C. P., Ter Kuile, M. M., Lowik, M., Van Eijkeren, M. A., Trimbos, J. B., Kenter, G. G. (2006). An observational longitudinal study to evaluate miction, defecation, and sexual function after radical hysterectomy with pelvic lymphadenectomy for early-stage cervical cancer. International Journal of 
Gynecological Cancer: Official Journal of the International Gynecological Cancer Society, 16(3), 1119-29.

Radloff, L. S. (1977). The CES-D Scale. Applied Psychological Measurement, 1(3), 385401.

Schlesselman, J. (1974). Sample size requirements in cohort and case-control studies of disease. American Journal of Epidemiology, 99, 381-384.

Schlesselman, J. (1982). Case-control studies: Design, conduct, analysis. New York: Oxford University Press.

Siegel, R., Naishadham, D., \& Jemal, A. (2012). Cancer statistics, 2012. CA: A Cancer Journal for Clinicians, 62 (1), 10-29.

Sobin, L., Gospodarowicz, M., \& Wittekind, C. (Eds.). (2002). UICC International Union Against Cancer: TNM Classification of Malignant Tumours (6th ed.), (pp. 155-157). Geneva, Switzerland: John Wiley \& Sons.

Tangjitgamol, S., Manusirivithaya, S., Hanprasertpong, J., Kasemsarn, P., Soonthornthum, T., Leelahakorn, S., . . . Lapcharoen, O. (2007). Sexual dysfunction in Thai women with early-stage cervical cancer after radical hysterectomy. Journal of Gynecological Cancer: Official Journal of the International Gynecological Cancer Society, 17(5), 1104-12.

Testa, M. A., \& Simonnson, D. C. (1996). Assessment of quality-of-life outcomes. The New England Journal of Medicine, 334 (13).

The American Cancer Society. (2012, January). Treatment options for cervical cancer by stage. Retrieved from http://www.cancer.org/cancer/cervicalcancer/detailedguide/cervical-cancertreating-by-stage

Tsai, C., Bayliss, M. S., \& Ware, J. E. (1997). SF-36® Health Survey Annotated Bibliography (2 ${ }^{\text {nd }}$ Ed.). Boston, MA: Health Assessment Lab, New England Medical Center.

Tzung-Yi, T., Shu-Yi, C., Mei-Huei, T., Yi-Lin, S., Chih-Ming, H., \& Hui-Fang, S. (2011). Prevalence and associated factors of sexual dysfunction in cervical cancer patients. Journal of Sexual Medicine, 8(6), 1789-1796. doi: 10.1111/j.17436109.2010.01745.x

Vistad, I., Fossa, S. D., \& Dahl, A. A. (2006). A critical review of patient-rated quality of life studies of long-term survivors of cervical cancer. Gynecologic Oncology, 102 (3), 563-572. doi: 10.1016/j.ygyno.2006.03.050 
Vrzackova, P., Weiss, P., \& Cibula, D. (2010). Sexual morbidity following radical hysterectomy for cervical cancer. Expert Review of Anticancer Therapy, 10(7), 1037-1042. doi: $10.1586 /$ era. 10.89

Ware, J. E., \& Sherbourne, C. D. (1992). The MOS 36-item short-form health survey (SF-36). I. conceptual framework and item selection. Medical Care, 30(6), 473483.

Ware, J.E., Gandek, B., \& the IQOLA Project Group (1994). The SF-36® Health Survey: development and use in mental health research and the IQOLA Project. International Journal of Mental Health 23(2), 49-73.

Ware, J. E. (n.d.). SF-36 Health Survey Update. Retrieved from http://www.sf36.org/tools/sf36.shtml

Waterhouse, J., \& Metcalfe, M. (1986). Development of the sexual adjustment questionnaire. Oncology Nursing Forum, 13(3), 53-59.

Waterhouse, J., \& Metcalfe, M. (1991). Attitudes toward nurses discussing sexual concerns with patients. Journal of Advanced Nursing, 16(9), 1048-1054.

Wenzel, L., DeAlba, I., Habbal, R., Kluhsman, B. C., Fairclough, D., Krebs, L. U., . . . Aziz, N. (2005). Quality of life in long-term cervical cancer survivors. Gynecologic Oncology, 97(2), 310-317. doi: 10.1016/j.ygyno.2005.01.010

World Health Organization. (2012, November 11). BMI classification. Retrieved from http://apps.who.int/bmi/index.jsp?introPage=intro 3. html

WHO/ICO Information Centre on HPV and Cervical Cancer (HPV Information Centre) (2010). Human Papillomavirus and Related Cancers in World (Summary Report 2010). Retrieved from www.who.int/hpvcentre

WHO/ICO Information Centre on HPV and Cervical Cancer (2013). Data query. Retrieved from http://apps.who.int/hpvcentre/statistics/dynamic/ico/DataQuerySelect.cfm 


\section{APPENDICES}

\section{APPENDIX A: VARIABLE DESCRIPTIONS AND CODING}

\section{VARIABLE DESCRIPTIONS AND CODING ${ }^{a}$}

\begin{tabular}{|c|c|c|c|}
\hline $\begin{array}{l}\text { Question } \\
\text { Number } \\
\end{array}$ & $\begin{array}{l}\text { Variable } \\
\text { Name }\end{array}$ & Range of Answers & Description \\
\hline \multicolumn{4}{|c|}{ Section 1- General Health (SF-36) } \\
\hline GH1 & GEN_HLTH & Excellent-Poor & Subjects opinion on current health \\
\hline $\mathrm{GH} 2$ & HLTH_NOW & Much better now-much worse now & $\begin{array}{l}\text { Subjects opinion on current health as compared to } 1 \\
\text { year ago }\end{array}$ \\
\hline \multirow{2}{*}{$\begin{array}{l}\mathrm{GH3} \\
\text { (sub-questions } \\
\text { A-J) }\end{array}$} & & Limited a lot-not limited at all & Limitations on daily activities because of health \\
\hline & $\begin{array}{l}\text { VIG_ACTV } \\
\text { MOD_ACTV } \\
\text { LFT_GROC } \\
\text { SEV_STRS } \\
\text { ONE_STR } \\
\text { BENDING }\end{array}$ & & $\begin{array}{l}\text { Vigorous activity } \\
\text { Moderate activity } \\
\text { Lifting groceries } \\
\text { Several flights of stairs } \\
\text { One flight of stairs } \\
\text { Bending, kneeling }\end{array}$ \\
\hline
\end{tabular}




\begin{tabular}{|c|c|c|c|}
\hline & $\begin{array}{l}\text { WALK_MIL } \\
\text { SEV_YRDS } \\
\text { ONE_YRD } \\
\text { BATHING }\end{array}$ & & $\begin{array}{l}\text { Walking } 1 \mathrm{mi}+ \\
\text { Walking several hundred yards } \\
\text { Walking } 100 \text { yards } \\
\text { Bathing and dressing }\end{array}$ \\
\hline \multirow[t]{2}{*}{ GH5 } & & All of the time-none of the time & $\begin{array}{l}\text { Did the subject experience problems with work /daily } \\
\text { activities due to emotional problems during last } 4 \\
\text { weeks }\end{array}$ \\
\hline & $\begin{array}{l}\text { EMOT_TIM } \\
\text { EMOT_ACM } \\
\text { EMOT_WRK }\end{array}$ & & $\begin{array}{l}\text { Cut down on amount of time spent on work } \\
\text { Accomplished less than desired } \\
\text { Less careful with work/activities }\end{array}$ \\
\hline$\overline{\text { GH6 }}$ & PHYSNTRF & & $\begin{array}{l}\text { Physical/emotional health's interference with normal } \\
\text { social life }\end{array}$ \\
\hline GH7 & $\begin{array}{l}\text { PAIN_4WK } \\
\text { PAINRLTD }\end{array}$ & $\begin{array}{l}\text { None-severe } \\
\text { Cervical disease or other? }\end{array}$ & $\begin{array}{l}\text { Bodily pain in last } 4 \text { weeks } \\
\text { What is pain related to }\end{array}$ \\
\hline \multirow[t]{2}{*}{$\overline{\mathrm{GH} 8}$} & & All of the time-none of the time & Feelings over last 4 weeks \\
\hline & $\begin{array}{l}\text { 4WK_PEP } \\
\text { 4WK_NERV } \\
\text { 4WK_DOWN } \\
\text { 4WK_CALM } \\
\text { 4WK_NRGY } \\
\text { 4WK_DPRS } \\
\text { 4WK_WORN }\end{array}$ & & $\begin{array}{l}\text { Full of pep? } \\
\text { Been nervous? } \\
\text { Down and nothing heightens spirit } \\
\text { Felt calm? } \\
\text { Lots of energy? } \\
\text { Felt depressed } \\
\text { Worn out? }\end{array}$ \\
\hline
\end{tabular}




\begin{tabular}{|c|c|c|c|}
\hline & $\begin{array}{l}\text { 4WK_HAPY } \\
4 \mathrm{WK} \_T I R D\end{array}$ & & $\begin{array}{l}\text { Been happy? } \\
\text { Felt tired? }\end{array}$ \\
\hline$\overline{\text { GH9 }}$ & 4WK_NTRF & all time-none time & Physical/emotional interference with social activities \\
\hline \multicolumn{4}{|c|}{ Section 1- Diagnostic and Treatment Information } \\
\hline \multirow[t]{2}{*}{$\overline{\text { DT1 }}$} & & Yes or No & Diagnosis \\
\hline & $\begin{array}{l}\text { INVASIVE } \\
\text { CIS }\end{array}$ & & $\begin{array}{l}\text { Invasive Disease } \\
\text { In situ }\end{array}$ \\
\hline$\overline{\text { DT4 }}$ & $\begin{array}{l}\text { SURG_TX } \\
\text { SURG_OVR } \\
\text { AFTR_OVR }\end{array}$ & $\begin{array}{l}\text { Yes or No } \\
\text { Yes or No } \\
\text { Yes or No }\end{array}$ & $\begin{array}{l}\text { Surgery as treatment } \\
\text { Ovaries removed during surgery } \\
\text { Ovaries removed after surgery }\end{array}$ \\
\hline \multirow[t]{2}{*}{ DT5 } & & Yes or No & Treatment \\
\hline & $\begin{array}{l}\text { THRP_RAD } \\
\text { THRP_IMP } \\
\text { THRP_CHM } \\
\text { THRP_HRM } \\
\text { THRP_OTR } \\
\text { OTHR_SPC }\end{array}$ & & \begin{tabular}{|l} 
Radiation \\
Radiation implants \\
Chemo \\
Hormone therapy \\
Other \\
Specification of other
\end{tabular} \\
\hline \multirow[t]{2}{*}{$\overline{\text { DT6 }}$} & & & Conditions due to cervical disease or cancer \\
\hline & $\begin{array}{l}\text { DIAR_BWL } \\
\text { NABLBLDR }\end{array}$ & $\begin{array}{l}\text { Yes or No } \\
\text { Yes or No }\end{array}$ & $\begin{array}{l}\text { Diarrhea } \\
\text { Bladder incontinence }\end{array}$ \\
\hline
\end{tabular}




\begin{tabular}{|c|c|c|c|}
\hline & $\begin{array}{l}\text { PAIN_SEX } \\
\text { VAG_DSRG } \\
\text { PAIN_WLK } \\
\text { OTHER } \\
\text { OTR_SPEC } \\
\text { MPCT_QOL } \\
\text { DESCRIBE }\end{array}$ & $\begin{array}{l}\text { Yes or No } \\
\text { Yes or No } \\
\text { Yes or No } \\
\text { Yes or No } \\
\text { Yes or No }\end{array}$ & $\begin{array}{l}\text { Painful intercourse } \\
\text { Vaginal discharge } \\
\text { Pain walking } \\
\text { Other } \\
\text { Specification } \\
\text { Did conditions impact QOL } \\
\text { Elaborate }\end{array}$ \\
\hline \multicolumn{4}{|c|}{ Section 1-Other Medical Conditions } \\
\hline \multirow[t]{2}{*}{$\mathrm{MCl}$} & & Yes or No & Heart Problems \\
\hline & $\begin{array}{l}\text { HRT_ATCK } \\
\text { HRT_FAIL } \\
\text { HRT_BYPS } \\
\text { STROKE } \\
\text { DIF_MOV }\end{array}$ & & $\begin{array}{l}\text { Heart attack } \\
\text { Heart failure } \\
\text { Bypass } \\
\text { Stroke } \\
\text { Paralysis due to stroke }\end{array}$ \\
\hline $\mathrm{MC2}$ & ASTHMA & Yes or No & Asthma \\
\hline MC3 & LUNG_DIS & Yes or No & Emphysema, chronic bronchitis, COPD \\
\hline$\overline{\mathrm{MC} 4}$ & STOM_ULC & Yes or No & Stomach ulcers of peptic ulcer disease \\
\hline MC5 & DIABETES & Yes or No & Diabetes \\
\hline MC6 & KIDN_DIS & Yes or No & Kidney Disease \\
\hline$\overline{M C 7}$ & RHUMARTH & Yes or No & Rheumatoid arthritis \\
\hline
\end{tabular}




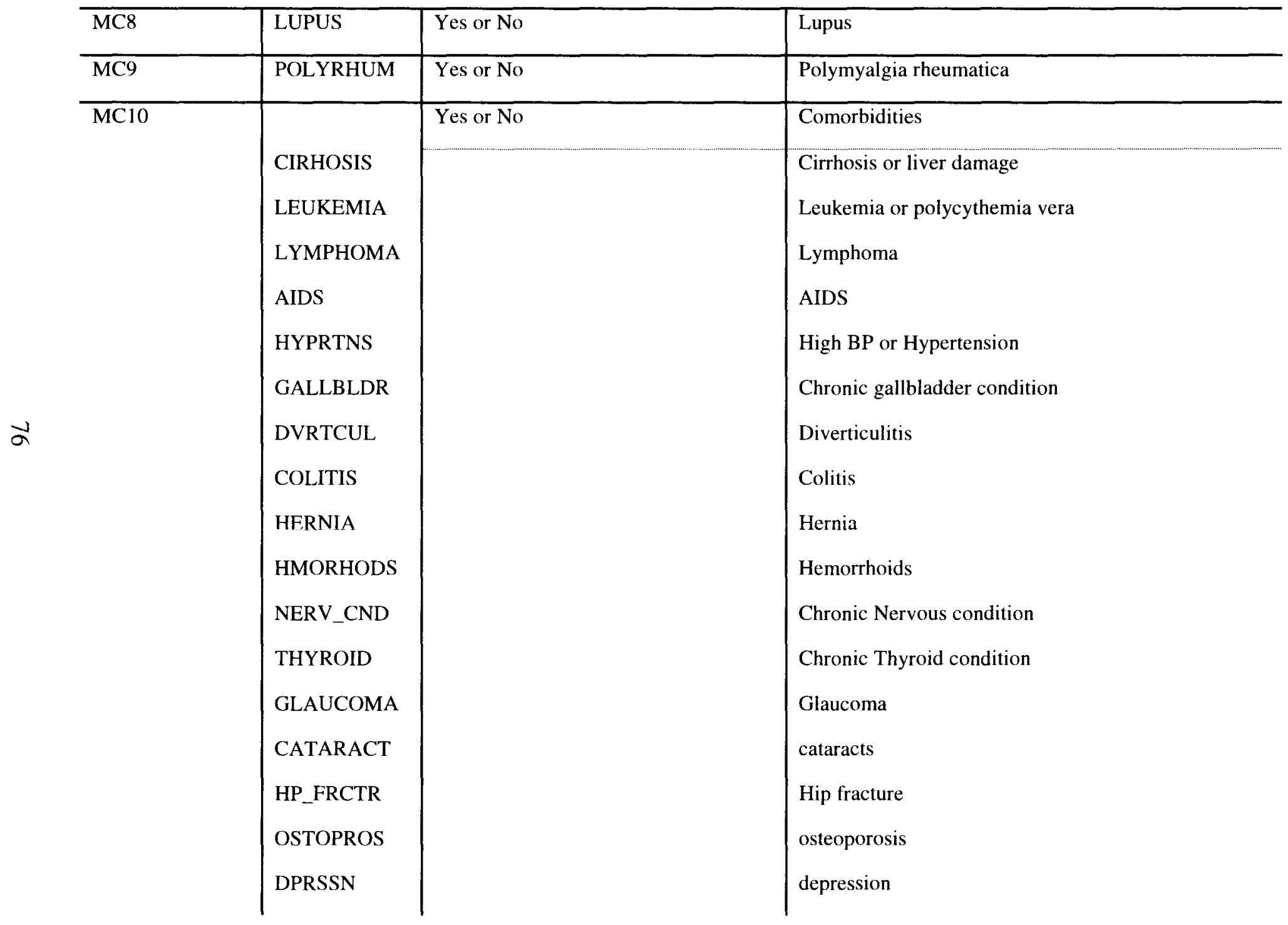




\begin{tabular}{|c|c|c|c|}
\hline & $\begin{array}{l}\text { DPRSRLTD } \\
\text { OBESITY } \\
\text { OTHR_CA } \\
\text { CA_TYPES } \\
\text { OTHR_HLT }\end{array}$ & & $\begin{array}{l}\text { Depression related to Cervical disease or cervical } \\
\text { cancer } \\
\text { Obesity } \\
\text { Other Cancers } \\
\text { Specify Cancer } \\
\text { Other health problems }\end{array}$ \\
\hline \multirow[t]{9}{*}{ MC11 } & & & STDS and Year of diagnosis \\
\hline & GEN_WRTS & Yes or No & Genital Warts \\
\hline & GEN_HRPS & Yes or No & Herpes \\
\hline & TRCOMNAS & Yes or No & Trichomonas \\
\hline & CHLAMDIA & Yes or No & Chlamydia \\
\hline & GONORHEA & Yes or No & Gonorrhea \\
\hline & SYPHLIS & Yes or No & Syphilis \\
\hline & PID & Yes or No & Pelvic Inflammatory Disease \\
\hline & HPV & Yes or No & Human papillomavirus \\
\hline \multicolumn{4}{|c|}{ Section 2- Thought and Attitudes } \\
\hline \multirow[t]{3}{*}{$\overline{T A 1}$} & \multirow{3}{*}{$\begin{array}{l}\text { QOL_2Y } \\
\text { QOL_NOW }\end{array}$} & Excellent-Poor & Rating QOL (excellent-poor) \\
\hline & & & @ 2 years \\
\hline & & & Now \\
\hline TA2 & QOL_CVCA & Yes or No & Current QOL impacted by Cervical Disease \\
\hline TA4 & & Rarely-most of the time & CES-D Scale (Feelings occurred within the last week) \\
\hline
\end{tabular}




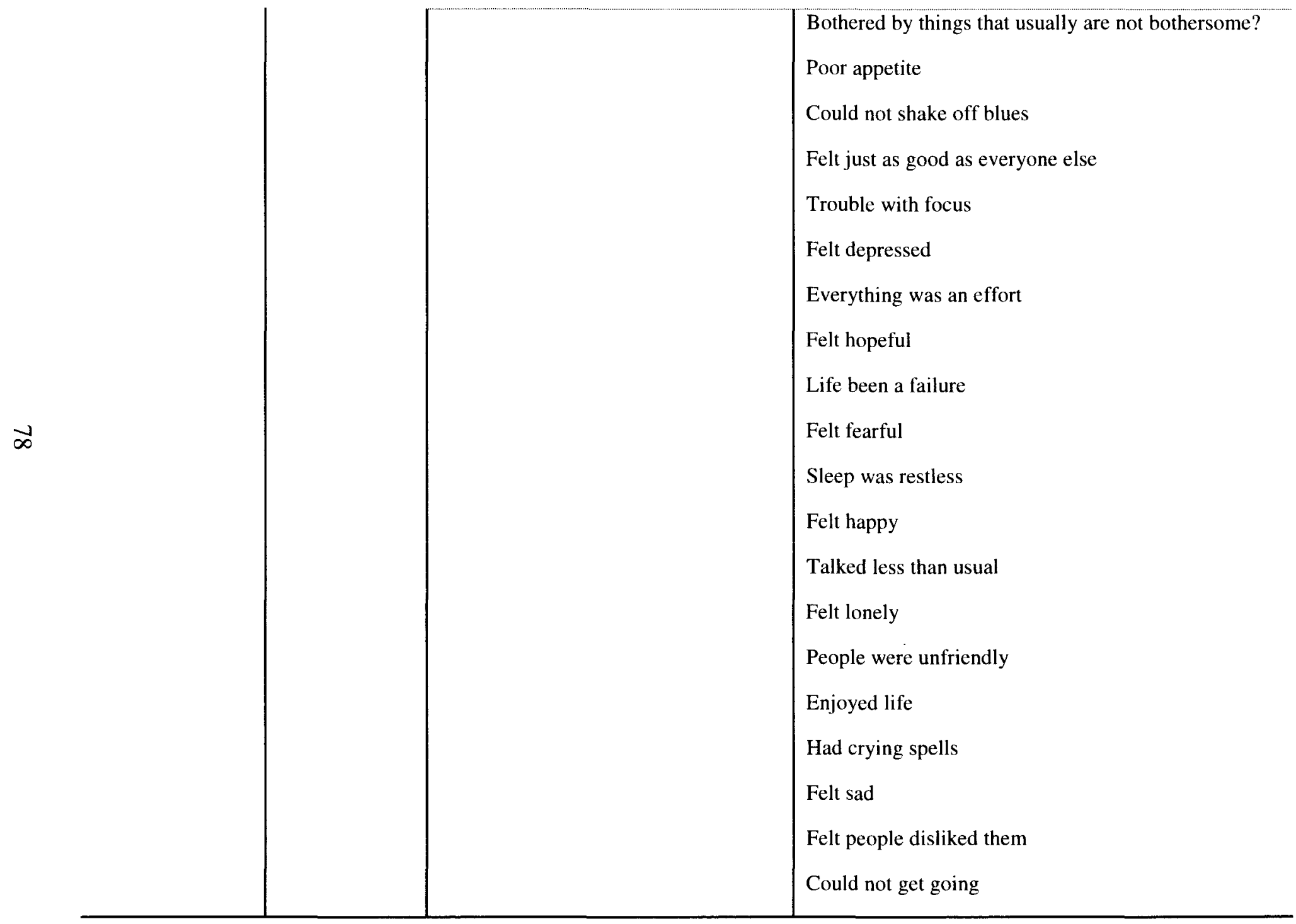




\begin{tabular}{|c|c|c|c|}
\hline \multicolumn{4}{|c|}{ Section 3- Screening, Reproductive, and Menstrual History } \\
\hline RS7 & $\begin{array}{l}\text { INTRCORS } \\
\text { AGE_SEX } \\
\text { BDX_SEX } \\
\text { ADX_SEX }\end{array}$ & $\begin{array}{l}\text { Yes or NO } \\
\text { Age } \\
\text { Number } \\
\text { Number }\end{array}$ & $\begin{array}{l}\text { Intercourse with man? } \\
\text { Age of } 1^{\text {st }} \text { time } \\
\text { \# of men before diagnosis } \\
\text { \# of men after diagnosis }\end{array}$ \\
\hline$\overline{R S 8}$ & SEXIMPNW & Extremely- of No Importance & Importance of sex \\
\hline RS9 & SEXNJYNW & Always-No activity & How often is sex enjoyable \\
\hline RS10 & SEX_DESR & Always-Never & Desire for sex \\
\hline RS11 & DSR_OFTN & Always- Never & Desires for sex is greater than partner's desire \\
\hline$\overline{\mathrm{RS} 12}$ & SEX_SAT & Always-Never & Satisfied after sexual activity \\
\hline$\overline{\mathrm{RS} 13}$ & FREQ_SAT & Very satisfied- Very unsatisfied & Satisfied with frequency \\
\hline RS14 & SEX_TENS & Always- never & Tense after sexual experience \\
\hline$\overline{R S 15}$ & CAFX_SEX & Very bad-very good & Effect of diagnosis on sexual relationship \\
\hline$\overline{\mathrm{RS} 16}$ & ADX_MENS & $\begin{array}{l}\text { Currently having periods- no longer } \\
\text { having periods }\end{array}$ & At time of diagnosis, what was menstrual status \\
\hline RS17 & NOW_MENS & $\begin{array}{l}\text { Currently having periods- no longer } \\
\text { having periods }\end{array}$ & Now what is menstrual status \\
\hline$\overline{\mathrm{RS} 18}$ & HSTRCTMY & Yes or No & Hysterectomy \\
\hline$\overline{\text { RS24 }}$ & $\begin{array}{l}\text { TX_NFRTL } \\
\text { FRTL_TX }\end{array}$ & $\begin{array}{l}\text { Yes or No } \\
\text { Yes or No }\end{array}$ & $\begin{array}{l}\mathrm{CC} \text { treatment render infertile } \\
\text { Fertility treatments tried }\end{array}$ \\
\hline$\overline{\mathrm{RS} 25}$ & NFRTLRSK & Yes or No & Discussion of infertility risks with physician \\
\hline
\end{tabular}


$\cdot$

\begin{tabular}{|c|c|c|c|}
\hline \multicolumn{4}{|c|}{ Section 3- Health and Family History } \\
\hline HF1 & $\begin{array}{l}\text { HGHT_FT } \\
\text { HGHT_IN }\end{array}$ & $\begin{array}{l}\text { feet } \\
\text { inches }\end{array}$ & Current height \\
\hline HF3 & NOW_WGT & lbs & Current weight \\
\hline \multicolumn{4}{|c|}{ Section 4-Lifestyle Information } \\
\hline LI1 & $\begin{array}{l}\text { SMOK_LIF } \\
\text { NOW_SMOK }\end{array}$ & $\begin{array}{l}\text { Yes or No } \\
\text { Every day, some days, not at all }\end{array}$ & $\begin{array}{l}\text { Have your smoked at least } 100 \text { cigarettes in lifetime } \\
\text { Currently smoke }\end{array}$ \\
\hline LI2 & HAD_DRNK & Yes or No & 1 drink in last month \\
\hline LI9 & PA_MONTH & Yes or No & Physical activity in last month \\
\hline \multicolumn{4}{|c|}{ Section 4- Demographic Data } \\
\hline DDI & $\begin{array}{l}\text { DOB } \\
\text { AGE }\end{array}$ & & $\begin{array}{l}\text { Date of Birth } \\
\text { Years old }\end{array}$ \\
\hline DD3 & $\begin{array}{l}\text { MARR_ADX } \\
\text { MARR_NOW }\end{array}$ & $\begin{array}{l}\text { Married, widowed, divorced, } \\
\text { separated, other, never married } \\
\text { Married, widowed, divorced, } \\
\text { separated, other, never married }\end{array}$ & $\begin{array}{l}\text { Married at diagnosis } \\
\text { Married now }\end{array}$ \\
\hline DD5 & NOW_SCHL & $\begin{array}{l}8^{\text {th }} \text { grade or less, some high school, } \\
\text { high school grad, some college, } \\
\text { college grad, grad school }\end{array}$ & Level of schooling completed \\
\hline DD8 & NOW_INCM & Pick code & Pretax Income now \\
\hline DD9 & NO_INS & Yes or No & No insurance \\
\hline DD12 & SLF_ETHN & & Ethnicity \\
\hline
\end{tabular}

${ }^{\mathrm{a}} \mathrm{All}$ variables included in dataset. Not all were included in analysis 


\section{APPENDIX B: CERVICAL CANCER STUDIES}

\begin{tabular}{|c|c|c|c|c|c|c|}
\hline \multicolumn{7}{|c|}{ Cervical Cancer Studies $^{a}$} \\
\hline Author & Design & Aims & Cancer Types & Treatment Types & Results & Covariates \\
\hline $\begin{array}{l}\text { Abitol and } \\
\text { Davenport } \\
\text { (1974) }\end{array}$ & $\begin{array}{l}\text { Clinical } \\
\text { Series }\end{array}$ & $\begin{array}{l}\text { 1. Effect of therapy } \\
\text { on sexual } \\
\text { function } \\
\text { 2. Associations with } \\
\text { changes in } \\
\text { vaginal anatomy }\end{array}$ & Invasive Only & $\begin{array}{ll}- & \text { Radiation (28) } \\
- & \text { Surgery (32) } \\
- & \text { Combination } \\
& (15)\end{array}$ & $\begin{array}{l}\text { 22/28 subjects given radiation } \\
\text { had anatomical changes } \\
\text { sufficient to cause sexual } \\
\text { dysfunction } \\
\text { 2/32 surgical patients had } \\
\text { changes in anatomy sufficient } \\
\text { to cause sexual dysfunction } \\
\text { Combination treatment group } \\
33 \% \text { with sexual dysfunction }\end{array}$ & None Available \\
\hline $\begin{array}{l}\text { Bartoces, } \\
\text { Serverson, } \\
\text { Rusin, } \\
\text { Schwartz, } \\
\text { Ruterbusch, and } \\
\text { Neale } \\
(2009)\end{array}$ & $\begin{array}{l}\text { Case-Case } \\
\text { Comparison }\end{array}$ & $\begin{array}{ll}\text { 1. } & \text { Determine } \\
\text { quality of life } \\
\text { differences } \\
\text { between invasive } \\
\text { and noninvasive } \\
\text { long term } \\
\text { cervical cancer } \\
\text { survivors } \\
\text { 2. Evaluate } \\
\text { associations } \\
\text { between quality } \\
\text { of life and self- } \\
\text { esteem }\end{array}$ & $\begin{array}{ll}-\quad & \text { Invasive (42) } \\
- & \text { Noninvasive } \\
& (103)\end{array}$ & Surgery Only & $\begin{array}{l}\text { Invasive group more likely to } \\
\text { report income of }<\$ 10,000 \\
\text { Invasive group NOT } \\
\text { associated with ethnicity, age, } \\
\text { education, health insurance, } \\
\text { marital status, comorbidities, } \\
\text { relapse or HRT; } \\
\text { Similar self- esteem between } \\
\text { both groups }\end{array}$ & $\begin{array}{l}\text { Factors associated } \\
\text { with quality of life } \\
\text { (socioeconomic } \\
\text { factors, behavioral } \\
\text { characteristics, } \\
\text { psychosocial factors, } \\
\text { and comorbidities) }\end{array}$ \\
\hline
\end{tabular}




\begin{tabular}{|c|c|c|c|c|c|c|}
\hline $\begin{array}{l}\text { Baser, Li, and } \\
\text { Carter } \\
(2012)\end{array}$ & $\begin{array}{l}\text { Validity and } \\
\text { Reliability } \\
\text { testing }\end{array}$ & $\begin{array}{l}\text { Establish the validity } \\
\text { and reliability of the } \\
\text { Female Sexual } \\
\text { Function Index (FSFI) } \\
\text { in women cancer } \\
\text { survivors }\end{array}$ & $\begin{array}{ll}- & 4 \text { cohorts from } \\
& 3 \text { studies with } \\
\text { different } & \text { eligibility } \\
& \text { requirements } \\
\text { - } & \text { GYN1 (22) } \\
\text { - } & \text { GYN2 (47) } \\
\text { - } & \text { BMT (51) } \\
\text { - } & \text { CERV }(61) \\
\end{array}$ & $\begin{array}{ll}\text { - } & \text { Surgery } \\
\text { - } & \text { Chemotherapy } \\
\text { - } & \text { Radiation } \\
\text { - } & \text { HRT }\end{array}$ & $\begin{array}{l}\text { - Cronbach } \alpha \text { reliability score } \\
\text { was } 0.94\end{array}$ & None Available \\
\hline $\begin{array}{l}\text { Bergmark, } \\
\text { Avall- } \\
\text { Lundqvist, } \\
\text { Dickman, } \\
\text { Henningsohn, } \\
\text { and Steineck } \\
\text { (2006) }\end{array}$ & $\begin{array}{l}\text { Case- } \\
\text { Control }\end{array}$ & $\begin{array}{ll}\text { 1. } & \begin{array}{l}\text { Prevalence of } \\
\text { symptoms and } \\
\text { reduced function } \\
5 \text { years post } \\
\text { treatment } \\
\text { (Wertheim-Meigs }\end{array} \\
\text { procedure) } \\
\text { 2. } \begin{array}{l}\text { Determine } \\
\text { distress caused by } \\
\text { symptoms }\end{array} \\
\text { 3. } \begin{array}{l}\text { Determine } \\
\text { willingness of }\end{array} \\
\text { women to trade } \\
\text { years of life for } \\
\text { better quality of } \\
\text { life }\end{array}$ & $\begin{array}{ll} & \text { Early Stage } \\
\text { Cervical Cancer } \\
\text { (93) } \\
\text { Matched } \\
\text { controls }(350)\end{array}$ & $\begin{array}{ll}- & \text { Surgery } \\
\text { - } & \text { Radiotherapy }\end{array}$ & $\begin{array}{l}\text { 19\% of cases and } 3 \% \text { controls } \\
\text { with lymphedema ( } 25 \% \text { of } \\
\text { cases found it distressful) } \\
\text { Risk of inability to completely } \\
\text { void urinary bladder was } 9 \\
\text { times higher for cases than } \\
\text { controls } \\
19-35 \% \text { of sexually active } \\
\text { cases reported changes in } \\
\text { vaginal anatomy } \\
\text { Higher levels of distress with } \\
\text { regard to sexual functioning } \\
\text { (1.2 and } 1.1 \text { RR reported) }\end{array}$ & $\begin{array}{ll} & \text { Demographic } \\
\text { characteristics } \\
\text { - } & \text { Treatment } \\
\text { - } & \text { Medications and } \\
\text { Preexisting } \\
\text { conditions } \\
\text { - Cancer relapse } \\
\text { - HRT }\end{array}$ \\
\hline
\end{tabular}




\begin{tabular}{|c|c|c|c|c|c|c|}
\hline $\begin{array}{l}\text { Donovan, } \\
\text { Taliaferro } \\
\text { Alvarez } \\
\text { Jacobsen, } \\
\text { Roetzheim, and } \\
\text { Wenham } \\
(2007)\end{array}$ & $\begin{array}{l}\text { Case- } \\
\text { Control }\end{array}$ & $\begin{array}{l}\text { 1. Determine if } \\
\text { women treated } \\
\text { for cervical } \\
\text { cancer have } \\
\text { poorer sexual } \\
\text { health } \\
\text { 2. Determine if the } \\
\text { differences in } \\
\text { sexual health are } \\
\text { a demographics, } \\
\text { clinical, physical, } \\
\text { or psychosocial } \\
\text { factors }\end{array}$ & $\begin{array}{ll} & \text { Cervical cancer } \\
\text { patients with } \\
\text { stages 0-II (50) } \\
\text { Age matched } \\
\text { controls }(50)\end{array}$ & $\begin{array}{ll}- & \text { Surgery } \\
\text { - } & \text { Radiation } \\
\text { - } & \text { Chemotherapy } \\
\text { - } & \text { Combination }\end{array}$ & $\begin{array}{l}\text { Cases had significantly higher } \\
\text { mean scores in sexual } \\
\text { disinterest }(7.5 \pm 2.9) \text { and } \\
\text { dysfunction }(9.6 \pm 3.8) \text { and } \\
\text { significantly lower mean } \\
\text { scores in satisfaction }(3.9 \pm 2.1) \\
\text { Covariates associated with } \\
\text { decreased sexual function and } \\
\text { interest: less education, recent } \\
\text { diagnosis, radiation, poor } \\
\text { partner relations, negative } \\
\text { self-esteem, anatomical } \\
\text { changes } \\
\text { HRT increased sexual interest }\end{array}$ & $\begin{array}{ll}\text { - } & \text { Demographics } \\
\text { - } & \text { Clinical } \\
\text { characteristics } \\
\text { - } & \text { Physical factors } \\
\text { - } & \text { Psychosocial } \\
\text { factors }\end{array}$ \\
\hline $\begin{array}{l}\text { Frumovitz, } \\
\text { Sun, } \\
\text { Schover, } \\
\text { Munsell, } \\
\text { Jhingran, } \\
\text { Wharton, Eifel, } \\
\text { Bevers, } \\
\text { Levenback, } \\
\text { Gershenson, } \\
\text { and } \\
\text { Bodurka, } \\
\text { (2005) } \\
\end{array}$ & $\begin{array}{l}\text { Case- } \\
\text { Control }\end{array}$ & $\begin{array}{l}\text { 1. Compare quality } \\
\text { of life and sexual } \\
\text { functioning in } \\
\text { cervical cancer } \\
\text { survivors who } \\
\text { received different } \\
\text { treatment }\end{array}$ & $\begin{array}{l}\text { - Cervical Cancer } \\
\text { patients with } \\
\text { tumors } \leq 6 \mathrm{~cm} \\
(74) \\
\text { Age and race } \\
\text { matched } \\
\text { Controls }(40)\end{array}$ & $\begin{array}{ll}- & \text { Surgery (37) } \\
- & \text { Radiation (37) }\end{array}$ & $\begin{array}{ll} & \text { Radiation group had higher } \\
\text { stage of disease }(\mathrm{p}<0.001) \\
\text { Radiation group scored worse } \\
\text { for physical health scores } \\
(45.1 \mathrm{p}<0.001) \\
\text { Radiation group had overall } \\
\text { poorer sexual function as } \\
\text { scored by FSFI }(17.1 \mathrm{p} 0.001)\end{array}$ & $\begin{array}{ll} & \text { Age } \\
- & \text { Marital Status } \\
- & \text { Religion } \\
- & \text { Education } \\
\text { - } & \text { BMI } \\
\text { - } & \text { Current smoking } \\
& \text { habits } \\
\text { - } & \text { Comorbidities } \\
\text { - } & \text { Menopausal } \\
& \text { symptom score }\end{array}$ \\
\hline
\end{tabular}




\begin{tabular}{|c|c|c|c|c|c|c|}
\hline $\begin{array}{l}\text { Gotay, } \\
\text { Farley, } \\
\text { Kawamoto, and } \\
\text { Mearig } \\
(2008)\end{array}$ & $\begin{array}{l}\text { Case-Case } \\
\text { Comparison }\end{array}$ & $\begin{array}{l}\text { 1. Assess quality of } \\
\text { life of long term } \\
\text { cervical cancer } \\
\text { survivors in the } \\
\text { military health } \\
\text { system } \\
\text { Assess the } \\
\text { ability of } \\
\text { researchers to use } \\
\text { the Department } \\
\text { of Defense's } \\
\text { Automated } \\
\text { Central Tumor } \\
\text { Registry } \\
\text { (ACTUR) }\end{array}$ & $\begin{array}{l}\text { Invasive Only } \\
\text { (41) } \\
\text { SF-36 scores } \\
\text { compared to } \\
\text { scores gathered } \\
\text { from } \\
\text { respondents to } \\
\text { the National } \\
\text { Health Survey } \\
\text { of Functional } \\
\text { Health Status }\end{array}$ & $\begin{array}{l}\text { Not an outcome } \\
\text { variable }\end{array}$ & $\begin{array}{l}\text { - Survivors had a higher overall } \\
\text { mental health scores } \\
(52.38 \pm 9.35) \text { as compared to } \\
\text { general population } \\
44 \% \text { of survivors indicated } \\
\text { cervical cancer had a negative } \\
\text { effect on their sexual } \\
\text { relationships }\end{array}$ & 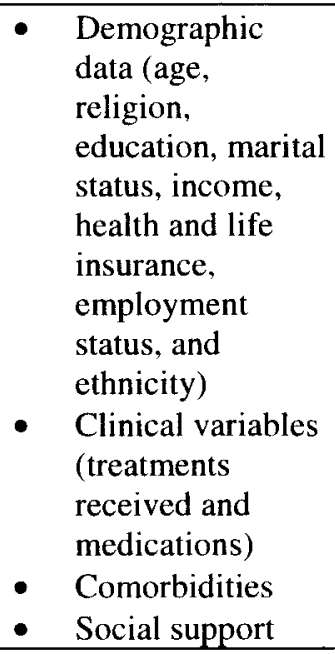 \\
\hline $\begin{array}{l}\text { Greenwald and } \\
\text { McCorkle } \\
2008\end{array}$ & $\begin{array}{l}\text { Case-Case } \\
\text { Comparison }\end{array}$ & $\begin{array}{ll}\text { 1. } & \text { Assess sexuality } \\
\text { and sexual } \\
\text { function in } \\
\text { women treated } \\
\text { for invasive } \\
\text { cervical cancer } \\
\text { 2. Determine, if } \\
\text { any, the effects of } \\
\text { surgery } \\
\text { (hysterectomy } \\
\text { and } \\
\text { oophorectomy) } \\
\text { on self-image and } \\
\text { sexuality }\end{array}$ & Invasive only (179) & $\begin{array}{ll}- & \text { Surgery } \\
- & \text { Radiation } \\
\text { - } & \text { HRT }\end{array}$ & $\begin{array}{ll}\text { Income } \geq \$ 60,000(\mathrm{OR} 0.26), \\
\text { Caucasian race (OR 0.16), and } \\
\text { diagnosis in stage I }(0.38) \\
\text { significantly predict sexual } \\
\text { outcomes. } \\
\text { - Hysterectomy reduced the } \\
\text { likelihood of decreased } \\
\text { desire(OR } 0.26) \\
\text { Hysterectomy with } \\
\text { oophorectomy increased risk } \\
\text { of lack of enjoyment ( OR } \\
21.10) \\
34 \% \text { of subjects reported } \\
\text { cervical cancer had a negative } \\
\text { impact on sex life. }\end{array}$ & $\begin{array}{ll} & \text { Demographics } \\
\text { - } & \text { Health status } \\
\text { - } & \text { Emotional state } \\
\text { - } & \text { Familth behaviors } \\
\text { - } & \text { Lifestyle } \\
\text { - } & \text { Employment } \\
& \text { status }\end{array}$ \\
\hline
\end{tabular}




\begin{tabular}{|c|c|c|c|c|c|c|}
\hline $\begin{array}{l}\text { Greimel, } \\
\text { Winter, } \\
\text { Kapp, and } \\
\text { Haas } \\
(2009)\end{array}$ & $\begin{array}{l}\text { Case- } \\
\text { Control }\end{array}$ & $\begin{array}{l}\text { Determine the long- } \\
\text { term side effects of } \\
\text { treatment options on } \\
\text { cervical cancer } \\
\text { survivors quality of } \\
\text { life and sexual } \\
\text { functioning }\end{array}$ & $\begin{array}{l}\text { Cervical Cancer } \\
\text { stages I-IV (121) } \\
\text { Normative } \\
\text { Reference data } \\
(1139)\end{array}$ & $\begin{array}{l}\text { Surgery alone } \\
(63) \\
\text { Surgery and } \\
\text { Chemotherapy } \\
(38) \\
\text { - Surgery and } \\
\text { Radiation }(20)\end{array}$ & $\begin{array}{l}\text { When compared with other } \\
\text { treatment groups, women who } \\
\text { underwent surgery and } \\
\text { radiation therapy had } \\
\text { significantly worse mean } \\
\text { scores for several quality of } \\
\text { life outcomes. } \\
\text { - Surgery and radiation group } \\
\text { reported significantly lower } \\
\text { frequency of sexual activity } \\
\text { than other two groups ( } p \\
0.006 \text { ) }\end{array}$ & $\begin{array}{ll} & \text { Socioeconomic } \\
& \text { variables } \\
\text { - } & \text { Medical variables }\end{array}$ \\
\hline $\begin{array}{l}\text { Jensen, } \\
\text { Groenvold, } \\
\text { Klee, Thranov, } \\
\text { Petersen, and } \\
\text { Machin } \\
(2004)\end{array}$ & $\begin{array}{l}\text { Case- } \\
\text { Control }\end{array}$ & $\begin{array}{l}\text { Describe the impact } \\
\text { of the radical } \\
\text { hysterectomy on } \\
\text { sexual function }\end{array}$ & Stage I or II & $\begin{array}{ll}- & \text { Radical } \\
\text { hysterectomy } \\
\text { (173) } \\
\text { Age-matched } \\
\text { controls (328) }\end{array}$ & $\begin{array}{l}\text { Cases were found to be at } \\
\text { increased risk of several } \\
\text { symptoms of sexual } \\
\text { dysfunction throughout the } \\
\text { different time periods. The } \\
\text { relative risk for these } \\
\text { symptoms ranged from 1.2-4.1 } \\
\text { depending on the symptom } \\
\text { and time since treatment. }\end{array}$ & $\begin{array}{ll}\text { - } & \text { Socioeconomic } \\
& \text { factors } \\
\text { - } & \text { Menopausal } \\
& \text { status } \\
\text { - } & \text { HRT }\end{array}$ \\
\hline $\begin{array}{l}\text { Juraskova, } \\
\text { Butow, Bonner, } \\
\text { Robertson, } \\
\text { Sharpe } \\
(2011)\end{array}$ & $\begin{array}{l}\text { Case- } \\
\text { Control }\end{array}$ & $\begin{array}{l}\text { Evaluate sexual } \\
\text { adjustment of women } \\
\text { with early stage } \\
\text { cervical and } \\
\text { endometrial cancer }\end{array}$ & 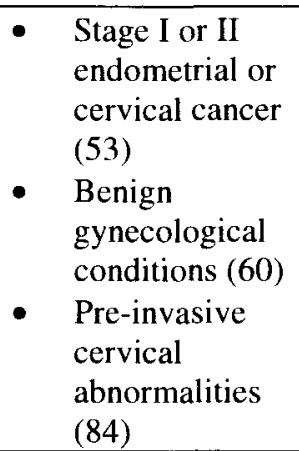 & $\begin{array}{ll}\text { - } & \text { Radical } \\
\text { - } & \text { hysterectomy } \\
\text { - colposcopy }\end{array}$ & $\begin{array}{l}\text { No significant differences among } \\
\text { groups }\end{array}$ & $\begin{array}{ll}\text { - } & \text { Socioeconomic } \\
& \text { factors } \\
\text { - } & \text { Religion } \\
\text { - } & \text { Parity } \\
\text { - } & \text { HRT } \\
\text { - } & \text { Psychiatric } \\
& \text { therapy of } \\
& \text { medication } \\
\text { - } & \text { Depression }\end{array}$ \\
\hline
\end{tabular}




\begin{tabular}{|c|c|c|c|c|c|c|}
\hline $\begin{array}{l}\text { Lindau, } \\
\text { Gavrilova, and } \\
\text { Anderson, } \\
(2007)\end{array}$ & $\begin{array}{l}\text { Case- } \\
\text { Control }\end{array}$ & $\begin{array}{l}\text { Compare } \\
\text { sexuality of long } \\
\text { term vaginal and } \\
\text { cervical cancer } \\
\text { survivors to } \\
\text { national norms } \\
\text { Evaluate the care } \\
\text { received for } \\
\text { sexual problems. }\end{array}$ & $\begin{array}{l}\text { Adenocarcinom } \\
\text { a of the cervix } \\
\text { and/or the } \\
\text { vagina }(160) \\
\text { Normative } \\
\text { controls }(320)\end{array}$ & $\begin{array}{ll}- & \text { Surgery } \\
- & \text { Radiation }\end{array}$ & $\begin{array}{l}\text { Higher prevalence of sexual } \\
\text { problems among cases ( } \mathrm{p} \\
0.02-<0.001 \text { ) } \\
\text { Frequency of sexual activity } \\
\text { lower in cases than in controls } \\
\text { (p } 0.002) \\
\text { Increased risk of several } \\
\text { sexual problems found in } \\
\text { cases (odds ratios range from } \\
2.33-10.47)\end{array}$ & $\begin{array}{ll}\text { - } & \begin{array}{l}\text { Socioeconomic } \\
\text { characteristics }\end{array} \\
\text { - } & \text { HRT } \\
\text { - } & \text { Partner status } \\
\text { - } & \text { Self-reported } \\
\text { health } \\
\text { - Patient-Physician } \\
\text { communication } \\
\text { regarding sex life } \\
\text { changes }\end{array}$ \\
\hline $\begin{array}{l}\text { Park, Bae, } \\
\text { Nam, Park, } \\
\text { Cho, Lee, } \\
\text { Lee, Kim, } \\
\text { Park, and Yun } \\
(2007)\end{array}$ & $\begin{array}{l}\text { Case- } \\
\text { Control }\end{array}$ & $\begin{array}{l}\text { Compare quality of } \\
\text { life and sexual } \\
\text { function in cervical } \\
\text { cancer survivors } \\
\text { versus the general } \\
\text { population }\end{array}$ & $\begin{array}{ll} & \text { Stage I-IV } \\
\text { cervical cancer } \\
\text { survivors }(860) \\
\text { Age-matched } \\
\text { controls }(494)\end{array}$ & $\begin{array}{ll}- & \text { Surgery only } \\
\text { - } & \text { Surgery and } \\
& \text { radiation } \\
\text { - } & \text { Radiation only }\end{array}$ & $\begin{array}{l}\text { - Cases scored more poorly than } \\
\text { controls in several areas } \\
\text { Radiation group had poorer } \\
\text { emotional functioning scores } \\
\text { (p<0.01) } \\
\text { When all treatment groups } \\
\text { were compared to controls, } \\
\text { cases had several symptoms of } \\
\text { poor quality of life and sexual } \\
\text { dysfunction }\end{array}$ & 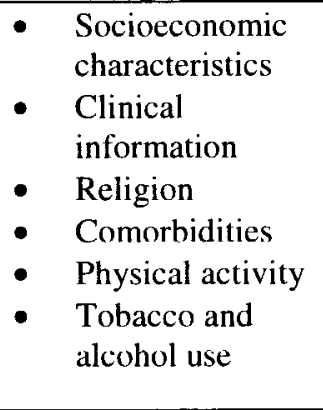 \\
\hline $\begin{array}{l}\text { Pieterse, Maas, } \\
\text { Ter Kuile, } \\
\text { Lowik, } \\
\text { Van Eijkeren, } \\
\text { Trimbos, and } \\
\text { Kenter } \\
(2006)\end{array}$ & $\begin{array}{l}\text { Case- } \\
\text { Control }\end{array}$ & $\begin{array}{l}\text { Evaluate negative } \\
\text { outcomes (miction, } \\
\text { defecation, and } \\
\text { sexuality) of } \\
\text { treatment of cervical } \\
\text { cancer problems with } \\
\text { radical hysterectomy. }\end{array}$ & $\begin{array}{ll} & \text { Stage 1-IIA } \\
& (73) \\
\text { - } & \text { Controls }(224)\end{array}$ & $\begin{array}{ll}- & \text { Radical } \\
\text { hysterectomy } \\
\text { only } \\
\text { - } & \text { Radical } \\
\text { hysterectomy } \\
\text { with radiation }\end{array}$ & $\begin{array}{l}\text { Cases were at increased risk of } \\
\text { sexual dysfunction and } \\
\text { dissatisfaction after surgery, } \\
\text { regardless of radiation } \\
\text { (Relative Risk } 3.3-4.3 \text { ) } \\
\text { Risk of dissatisfaction with } \\
\text { sex life increased as the post } \\
\text { treatment time increased } \\
\text { (Relative Risk 4.1-7.6) } \\
\text { Radiation therapy with surgery } \\
\text { increased the risk of no sexual } \\
\text { activity (Relative Risk 1.9) }\end{array}$ & $\begin{array}{ll}- & \Lambda \text { ge } \\
- & \text { HRT } \\
- & \text { Marital Status }\end{array}$ \\
\hline $\begin{array}{l}\text { Tangjitgamol } \\
\text { Manusirivithaya } \\
\text { Hanprasertpong } \\
\text {, Kasemsarn, }\end{array}$ & $\begin{array}{l}\text { Case-Case } \\
\text { Comparison }\end{array}$ & $\begin{array}{l}\text { Evaluate sexual } \\
\text { dysfunction in } \\
\text { association with } \\
\text { radical hysterectomies }\end{array}$ & Stage I-II (105) & $\begin{array}{l}\text { Radical } \\
\text { hysterectomy with } \\
\text { or without } \\
\text { chemotherapy }\end{array}$ & $\begin{array}{l}\text { Participants were found to } \\
\text { have an increase in sexual } \\
\text { dysfunction symptoms post- } \\
\text { treatment }\end{array}$ & $\begin{array}{l}\text { - } \quad \text { Variables relating } \\
\text { to home life } \\
\text { - } \quad \text { Comorbidities } \\
\text { - } \quad \text { Age }\end{array}$ \\
\hline
\end{tabular}




\begin{tabular}{|c|c|c|c|c|c|c|}
\hline $\begin{array}{l}\text { Soonthornthum, } \\
\text { Leelahakorn, } \\
\text { Thawaramara, } \\
\text { Lapcharoen, } \\
\text { and } \\
(2007)\end{array}$ & & $\begin{array}{l}\text { in women with early } \\
\text { stage cervical cancer } \\
\text { in Thailand }\end{array}$ & & & $\begin{array}{l}\text { HRT was associated with an } \\
\text { increased risk for a decrease in } \\
\text { sexual frequency (OR } 6.20 \mathrm{p} \\
0.010 \text { ) } \\
\text { Salpingo-oophorectomy was } \\
\text { found to increase the risk of a } \\
\text { decrease in sexual frequency } \\
\text { (OR } 2.42 \mathrm{p} 0.033 \text { ) }\end{array}$ & $\begin{array}{ll}- & \text { Menopausal } \\
& \text { Status } \\
\text { - } & \text { HRT } \\
\text { - } & \text { Socioeconomic } \\
\text { factors }\end{array}$ \\
\hline $\begin{array}{l}\text { Vistad, } \\
\text { Fossa, } \\
\text { Kristensen, and } \\
\text { Dahl } \\
(2007)\end{array}$ & $\begin{array}{l}\text { Cross- } \\
\text { Sectional }\end{array}$ & $\begin{array}{l}\text { Evaluate chronic } \\
\text { fatigue and other } \\
\text { variables in cervical } \\
\text { cancer survivors who } \\
\text { were } 5 \text { years post- } \\
\text { treatment and were } \\
\text { treated with radiation } \\
\text { therapy. }\end{array}$ & $\begin{array}{ll} & \text { Stage Ib2-IVa } \\
(91) \\
\text { - } & \text { Normative data }\end{array}$ & - Radiation & $\begin{array}{l}\text { - } 30 \% \text { of the sexually active } \\
\text { subjects were sexually active } \\
\text { versus } 53 \% \text { of the normative } \\
\text { sample } \\
\text { Significantly lower mean } \\
\text { score for pleasure (p } 0.01) \text { and } \\
\text { higher mean score for } \\
\text { discomfort }(\mathrm{P}<0.001) \text { during } \\
\text { sexual activity } \\
\text { Anxiety and depression was } \\
\text { more common among cervical } \\
\text { cancer survivors with chronic } \\
\text { fatigue than those who did not } \\
\text { have chronic fatigue. }\end{array}$ & $\begin{array}{l}\text { Demographics } \\
\text { - Clinical } \\
\text { characteristics } \\
\text { - Psychological } \\
\text { characteristics }\end{array}$ \\
\hline $\begin{array}{l}\text { Wenzel, } \\
\text { DeAlba, } \\
\text { Habbal, } \\
\text { Kluhsman, } \\
\text { Fairclough,. } \\
\text { Krebs, } \\
\text { Anton-Culver, } \\
\text { Berkowitz, and } \\
\text { Aziz } \\
(2005)\end{array}$ & $\begin{array}{l}\text { Case- } \\
\text { Control }\end{array}$ & $\begin{array}{l}\text { Investigate the QOL } \\
\text { in cervical cancer } \\
\text { survivors ( } 5-10 \text { years) } \\
\text { that were also of } \\
\text { childbearing age }\end{array}$ & $\begin{array}{ll}\text { - } & \text { Cervical Cancer } \\
\text { cases }(51) \\
\text { - }\end{array}$ & $\begin{array}{ll}\text { - } & \text { Surgery only } \\
\text { - } & \text { Surgery and } \\
\text { Radiation } \\
\text { - } & \text { surgery and } \\
\text { chemotherapy } \\
\text { - } & \text { Radiation only }\end{array}$ & $\begin{array}{l}\text { Overall mean scores for } \\
\text { quality of life were similar for } \\
\text { cases and controls. } \\
\text { Distress among survivors was } \\
\text { significantly associated with } \\
\text { age }(p<0.01), \text { social support } \\
(p<0.001), \text { more reproductive } \\
\text { concerns }(p<0.001), \text { worse } \\
\text { mental status }(p<0.0001) \text {, and } \\
\text { less spirituality }(p<0.01) \\
31 \% \text { of cases were not } \\
\text { sexually active } \\
\text { Several gynecologic problems } \\
\text { were found more common in }\end{array}$ & $\begin{array}{ll}\text { - } & \text { Demographics } \\
\text { - } & \text { Socioeconomic } \\
\text { factors } \\
\text { - } & \text { Cancer specific } \\
& \text { distress } \\
\text { - } & \text { Social support } \\
\text { - } & \text { Spirituality } \\
\text { - } & \text { Reproductive } \\
\text { - } & \text { Gyncerns } \\
\text { - } & \text { functioning } \\
\text { HRT }\end{array}$ \\
\hline
\end{tabular}




\begin{tabular}{|c|c|c|c|c|c|c|}
\hline & & & & & $\begin{array}{l}\text { cases than controls ( } \mathrm{p} \text { values } \\
\text { ranging from } 0.0143-0.0166 \text { ) } \\
\text { Cases who reported sexual } \\
\text { dysfunction were found to } \\
\text { have lower mean scores for } \\
\text { quality of life }(\mathrm{p}<0.01)\end{array}$ & \\
\hline $\begin{array}{l}\text { Tzung-Yi, T., } \\
\text { Mei-Huei, T., } \\
\text { Yi-Lin, S., } \\
\text { Chih-Ming, G., } \\
\text { \& Hui-Fang, S. } \\
\text { (2011) }\end{array}$ & $\begin{array}{l}\text { Cross- } \\
\text { Sectional }\end{array}$ & $\begin{array}{l}\text { Determine the } \\
\text { prevalence of sexual } \\
\text { dysfunction in Taiwan } \\
\text { and the factors } \\
\text { associated with sexual } \\
\text { dysfunction }\end{array}$ & 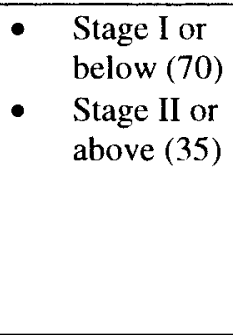 & $\begin{array}{ll} & \begin{array}{l}\text { One form of } \\
\text { treatment only }\end{array} \\
\text { Multiple forms } \\
\text { of treatment }\end{array}$ & $\begin{array}{l}\text { Increased risk of sexual } \\
\text { dysfunction later stages }\end{array}$ & $\begin{array}{ll}\text { - } & \text { Demographics } \\
\text { - } & \text { Sexual } \\
& \text { counseling } \\
\text { - } & \text { Employment } \\
& \text { status } \\
\text { - } & \text { Menstrual status } \\
\text { - Educational } \\
\end{array}$ \\
\hline $\begin{array}{l}\text { Vrzackova, } \\
\text { Weiss, \& } \\
\text { Cibula }\end{array}$ & Review & $\begin{array}{l}\text { Describe female } \\
\text { sexual dysfunction in } \\
\text { cervical cancer } \\
\text { patients treated with } \\
\text { radical hysterectomy }\end{array}$ & Not applicable & Not applicable & $\begin{array}{ll}\text { - } & \text { Female Sexual Dysfunction in } \\
\text { short term survivors found by } \\
\text { Jensen et al. }\end{array}$ & Not applicable \\
\hline
\end{tabular}

\footnotetext{
${ }^{\mathrm{a}}$ Refer to Reference List for more information about articles
} 


\section{APPENDIX C: SEXUAL HISTORY QUESTIONS AND RESPONSES}

\section{Sexual History Questions and Responses ${ }^{a, b}$}

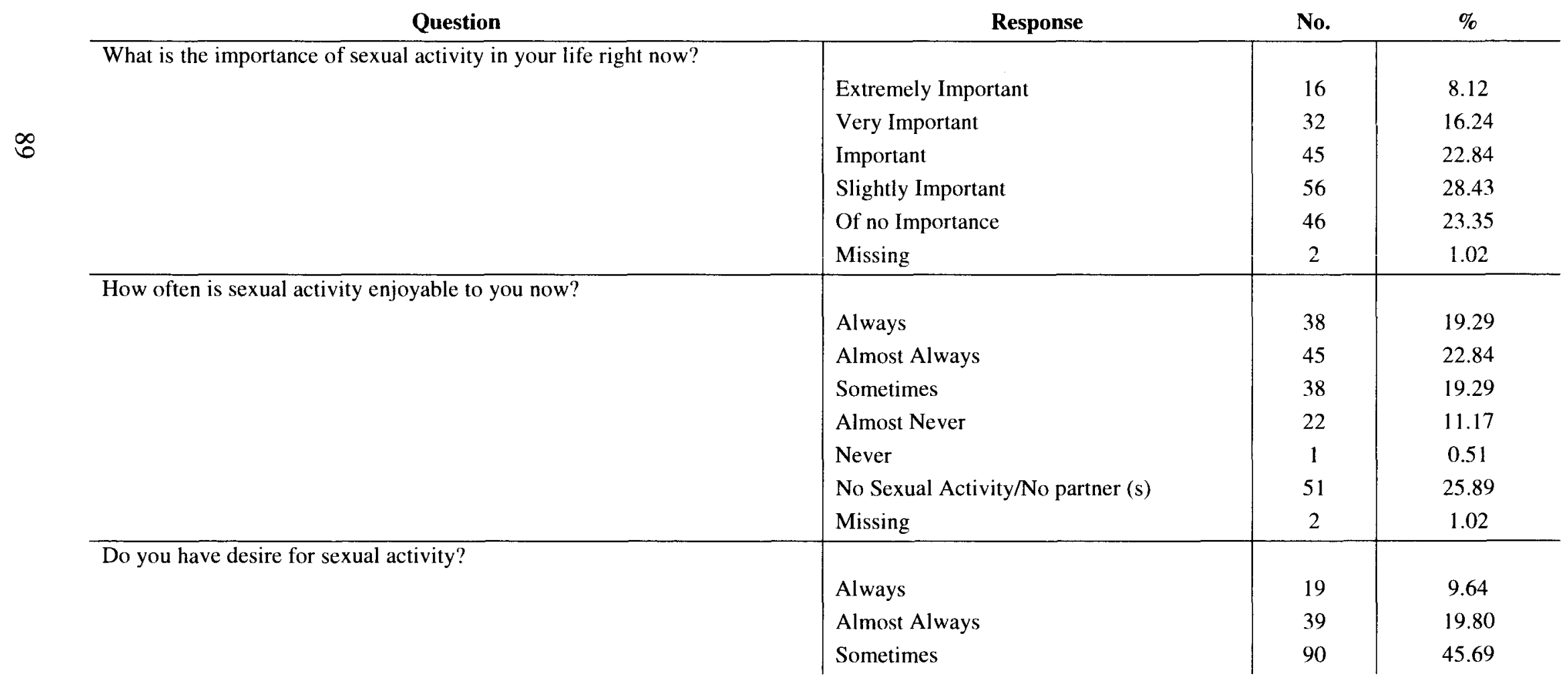




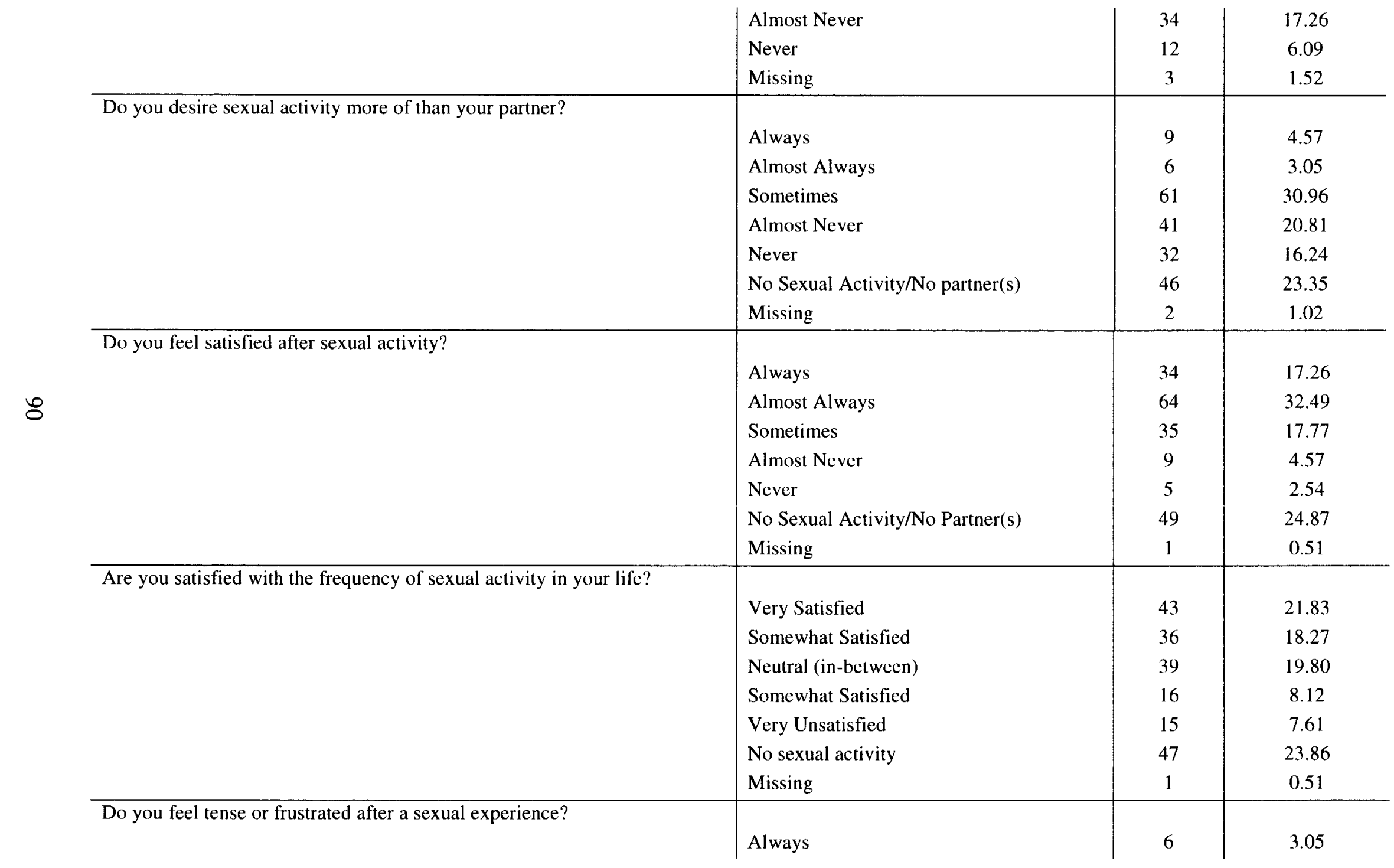




\begin{tabular}{|c|c|c|c|}
\hline & $\begin{array}{l}\text { Almost Always } \\
\text { Sometimes } \\
\text { Almost Never } \\
\text { Never } \\
\text { No Sexual Activity/ No partner(s) } \\
\text { Missing }\end{array}$ & $\begin{array}{c}4 \\
27 \\
39 \\
72 \\
47 \\
2\end{array}$ & $\begin{array}{l}2.03 \\
13.71 \\
19.80 \\
36.55 \\
23.86 \\
1.02\end{array}$ \\
\hline $\begin{array}{l}\text { What effect has your diagnosis of cervical disease/cancer had on your } \\
\text { sexual relationship with your partner(s)? }\end{array}$ & $\begin{array}{l}\text { Very Bad Effect } \\
\text { Some Bad Effect } \\
\text { No Effect } \\
\text { Some Good Effect } \\
\text { Very Good Effect } \\
\text { No Partner } \\
\text { Missing }\end{array}$ & $\begin{array}{c}20 \\
31 \\
97 \\
9 \\
9 \\
29 \\
2\end{array}$ & $\begin{array}{c}10.15 \\
15.74 \\
49.24 \\
4.57 \\
4.57 \\
14.72 \\
1.02\end{array}$ \\
\hline Composite Variable $^{c}$ & $\begin{array}{l}\text { Positive Response to all } 8 \text { questions } \\
\text { Negative Response to all } 8 \text { questions } \\
\text { Missing }\end{array}$ & $\begin{array}{l}40 \\
51 \\
106\end{array}$ & $\begin{array}{l}20.30 \\
25.89 \\
53.81\end{array}$ \\
\hline
\end{tabular}

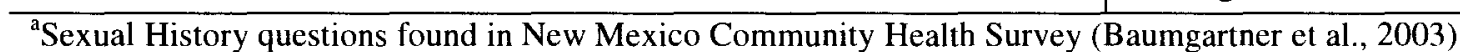

${ }^{b}$ All questions originally from the Sexual Adjustment Questionnaire (Waterhouse \& Metcalfe, 1986)

${ }^{\mathrm{c}}$ Variable created by including only positive or negative response to all 8 sexual history questions 


\section{APPENDIX D: TREATMENT OPTIONS BY STAGE OF DISEASE}

TREATMENT OPTIONS BY STAGE OF DISEASE

\begin{tabular}{|c|c|c|}
\hline Stage & $\begin{array}{c}\text { Sub- } \\
\text { categories }\end{array}$ & Treatment Options \\
\hline Stage 0 & & $\begin{array}{l}\text { - For carcinoma in situ, Cryosurgery, Laser surgery, LEEP/LLETZ, } \\
\text { or Cold knife conization } \\
\text { - For adenocarcinoma in situ, a hysterectomy or a cone biopsy until } \\
\text { preserving fertility is not an issue and then a hysterectomy }\end{array}$ \\
\hline \multirow[t]{2}{*}{ Stage IA } & IA1 & $\begin{array}{l}\text { - To Preserve fertility, cone biopsy with close observation for } \\
\text { reoccurrence } \\
\text { - Hysterectomy } \\
\text { - If cancer has invaded blood or lymph vessels and fertility needs to } \\
\text { be preserved, radical trachelectomy and removal of pelvic lymph } \\
\text { nodes } \\
\text { - If cancer has invaded blood or lymph vessels and fertility does not } \\
\text { need to be preserved, radical hysterectomy and removal of pelvic } \\
\text { lymph nodes. }\end{array}$ \\
\hline & IA2 & $\begin{array}{l}\text { - Radical hysterectomy and removal of pelvic lymph nodes } \\
\text { - Brachytherapy with or without external beam radiation to the } \\
\text { pelvis } \\
\text { - If preserving fertility, radical trachelectomy with removal of } \\
\text { pelvic lymph nodes }\end{array}$ \\
\hline \multirow[t]{2}{*}{ Stage IB } & IB 1 & $\begin{array}{l}\text { Radical hysterectomy with removal of pelvic lymph nodes (some } \\
\text { para-aortic lymph nodes can be removed as well) } \\
\text { - Radiation with brachytherapy and external beam radiation } \\
\text { - If preserving fertility, radical trachelectomy with removal of } \\
\text { pelvic lymph nodes (some para-aortic lymph nodes may need to } \\
\text { be removed as well) }\end{array}$ \\
\hline & IB2 & $\begin{array}{l}\text { - Brachytherapy with Cisplatin chemotherapy and radiation } \\
\text { - Radical hysterectomy with removal of pelvic lymph nodes } \\
\text { (radiation is sometimes needed depending on whether or not } \\
\text { cancer is found in the lymph nodes) } \\
\text { - Radiation followed by a hysterectomy }\end{array}$ \\
\hline
\end{tabular}




\begin{tabular}{|c|c|c|}
\hline \multirow[t]{2}{*}{ Stage II } & IIA & $\begin{array}{l}\text { - Brachytherapy and external radiation if tumor is greater than } 4 \mathrm{~cm} \\
\text { along with cisplatin chemotherapy } \\
\text { - Radiation and removal of the uterus } \\
\text { - Radical hysterectomy and removal of lymph nodes if tumor is less } \\
\text { than } 4 \mathrm{~cm} \text { (with the possibility of radiation, chemotherapy and } \\
\text { brachytherapy) }\end{array}$ \\
\hline & IIB & - Internal and external radiation and cisplatin \\
\hline $\begin{array}{l}\text { Stages III } \\
\text { and IVA }\end{array}$ & & - Internal and external radiation with cisplatin \\
\hline $\begin{array}{l}\text { Stage } \\
\text { IVB }\end{array}$ & & - Radiation to relieve symptoms and chemotherapy \\
\hline
\end{tabular}

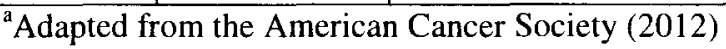




\section{CURRICULUM VITAE}

NAME: Katie F. Myatt

ADDRESS: 11602 Deham Drive,

Louisville, Kentucky, 40241

DOB: $\quad$ Louisville, Kentucky- May 20, 1986

EDUCATION

\& TRAINING: $\quad$ Bachelor of Arts, Biology

University of Louisville

August 2004-May 2008

AWARDS: University of Louisville School of Public Health and Information Sciences Scholarship Winner

Treasurer of Alpha Epsilon Delta (Pre-Health Honors Society)

Dean's List

Dean's Scholar

University of Louisville Scholarship Winner

Commonwealth Bank and Trust Student Star Scholarship Winner

Shelbyville Rotary Club Scholarship Winner

Kentucky County Treasurer's Association Scholarship Winner

Max Performance Scholarship Winner

INVITED PRESENTATIONS:

Kentucky Department for Public Health, 2012 Food Safety Conference 